Article

\title{
Destruction of Toluene, Naphthalene and Phenanthrene as Model Tar Compounds in a Modified Rotating Gliding Arc Discharge Reactor
}

\author{
Xiangzhi Kong ${ }^{1}$, Hao Zhang ${ }^{1, * \mathbb{C}}$, Xiaodong $\mathrm{Li}^{1, *}$, Ruiyang Xu ${ }^{1}$, Ishrat Mubeen ${ }^{2}, \mathrm{Li} \mathrm{Li}^{1}$ \\ and Jianhua Yan ${ }^{1}$ \\ 1 State Key Laboratory of Clean Energy Utilization, Zhejiang University, Hangzhou 310027, China; \\ lanklarde@126.com (X.K.); kaybyren@163.com (R.X.); 21727034@zju.edu.cn (L.L); yanjh@zju.edu.cn (J.Y.) \\ 2 Institute of Energy and Power Engineering, College of Mechanical Engineering, \\ Zhejiang University of Technology, Hangzhou 310013, China; ishrat.farman@gmail.com \\ * Correspondence: zhang_hao@zju.edu.cn (H.Z.); lixd@zju.edu.cn (X.L.); \\ Tel.: +86-571-87952438 (H.Z.); +86-571-87952037 (X.L.)
}

Received: 30 November 2018; Accepted: 21 December 2018; Published: 28 December 2018

\begin{abstract}
Tar removal is one of the greatest technical challenges of commercial gasification technologies. To find an efficient way to destroy tar with plasma, a rotating gliding arc (RGA) discharge reactor equipped with a fan-shaped swirling generator was used for model tar destruction in this study. The solution of toluene, naphthalene and phenanthrene is used as a tar surrogate and is destroyed in humid nitrogen. The influence of tar, $\mathrm{CO}_{2}$ and moisture concentrations, and the discharge current on the destruction efficiency is emphasized. In addition, the combination of $\mathrm{Ni} / \gamma-\mathrm{Al}_{2} \mathrm{O}_{3}$ catalyst with plasma was tested for plasma catalytic tar destruction. The toluene, naphthalene and phenanthrene destruction efficiency reached up to $95.2 \%, 88.9 \%$, and $83.9 \%$ respectively, with a content of $12 \mathrm{~g} / \mathrm{Nm}^{3}$ tar, $12 \%$ moisture, $15 \% \mathrm{CO}_{2}$, and a flow rate of $6 \mathrm{NL} / \mathrm{min}$, whereas $9.3 \mathrm{~g} / \mathrm{kW} \cdot \mathrm{h}$ energy efficiency was achieved. The increase of discharge current is advantageous in terms of decreasing black carbon production. The participation of $\mathrm{Ni} / \gamma-\mathrm{Al}_{2} \mathrm{O}_{3}$ catalyst shows considerable improvement in destruction efficiency, especially at a relatively high flow rate (over $9 \mathrm{NL} / \mathrm{min}$ ). The major liquid by-products are phenylethyne, indene, acenaphthylene and fluoranthene. The first two are majorly converted from toluene, acenaphthylene is produced by the co-reaction of toluene and naphthalene in the plasma, and fluoranthene is converted by phenanthrene.
\end{abstract}

Keywords: rotating gliding arc plasma; tar destruction; toluene; naphthalene; phenanthrene; catalyst

\section{Introduction}

Owing to the rapid consumption of fossil fuels and increasing emphasis on environmental issues, the use of biomass and municipal solid waste (MSW) as alternative fuel has received considerable attention. Gasification is considered one of the most flexible fuel conversion processes [1-3], which has the advantages of low secondary pollution compared with the traditional incineration method. The products of gasification can not only be used as fuel in gas turbines and gas engines, but also offer some basic building blocks for producing valuable chemicals, liquid fuels and hydrogen [4-6].

However, besides the useful fuels, tar exists in the syngas as an undesirable by-product, which can cause fouling, clogging, and corrosion problems in downstream equipment after cooling and condensing [1,6-9]. The secondary pollutants produced by the aromatic hydrocarbons in the tar component may also pose serious harm to the environment and human health. Tar removal, conversion and destruction is considered to be one of the greatest technical challenges, which must be overcome 
for the successful development of commercial gasification technologies [9-13]. Aromatic compounds are the most important contents in the tar, which are not only in large amounts but are chemically stable in the gasifier environment [14]. The traditional methods for the removal or destruction of tar can be categorized into (i) mechanical separation (by Venturi scrubbers, water scrubbers, electrostatic precipitators (ESPs), rotational particle separators, or cyclones), which is unattractive since it causes secondary pollution and wastage of chemical energy contained in tar while shows low efficiency in tar removal $[1,15,16]$; (ii) thermal cracking, which normally requires $1250{ }^{\circ} \mathrm{C}$ and takes a few seconds to get good results, and has the drawbacks of high cost and production of heavier products and agglomerated soot particles [17,18]; (iii) and catalytic cracking, which enables obtaining higher yields of valuable $\mathrm{H}_{2}$ and $\mathrm{CO}$ but has a significant limitation on the catalyst lifetime [2].

Non-thermal plasma methods, on the other hand, can tackle the drawbacks mentioned above. Various non-thermal plasma sources have been applied for the tar destruction, such as dielectric barrier discharges (DBDs) [19], corona discharges [20,21], microwave plasma [2,22-24], arc plasma [25,26], and gliding arc discharges (GAD) $[11,17,18,27-30]$. In non-thermal plasmas, the electrons have a high average temperature of $1-10 \mathrm{eV}$, which are highly excited to activate reactant molecules to form reactive species, such as radicals, excited species, ions, and photons, by electron impact excitation, ionization, and dissociation, etc., while the bulk gas temperature remains at low level (e.g., $800{ }^{\circ} \mathrm{C}$ ) [11]. In addition, the flexibility (high specific productivity, instant on/off, high energy density, power scalability) of non-thermal plasma systems provides a high adaptability to different application cases [31].

Recently, gliding arc discharge plasma has received much attention as an application to destroy or reform heavy hydrocarbons, and is considered to be a promising route to destroy tars from gasification. Pemen et al. [32] removed tars produced by biomass gasification with a gliding arc discharge. Nam et al. [27] used a three-blade gliding arc reactor to destruct benzene and naphthalene and obtained a destruction efficiency of $95 \%$ and $79 \%$ respectively. Gliding arc is a unique plasma, featuring the merits of both thermal plasmas (high energy density) and non-thermal plasmas (high energy efficiency) [33]. Most of the gliding arc power consumed $(75 \%-80 \%)$ is dissipated in the nonequilibrium zone meanwhile the specific energy input (SEI) can be up to $1 \mathrm{~kW} \cdot \mathrm{h} / \mathrm{m}^{2}$ [34], which means a good reaction capability can coexist with a high energy efficiency.

In this study, a modified atmospheric pressure rotating gliding arc (RGA) discharge reactor is developed for the destruction of tars. A fan-shaped swirling generator is innovatively equipped upstream the inner electrode, which provides a stable swirling flow field that is conducive to the stability of the arc. Unlike the limited planar plasma zone generated by traditional blade-type GAD, the arc generated by the RGA reactor can rotate rapidly and steadily without extinction (with a rotational frequency of up to 100 rotations per second [35]), creating a large three-dimensional plasma region. Previous work by our team has studied the destruction of toluene both in nitrogen and syngas atmospheres, where the destruction efficiency reached over 95\% [8,36]. Most of the work done by our team or others chose only one kind of substance as a tar surrogate injected into the reaction at one time (benzene, toluene, or naphthalene). However, the composition of actual tar is very complex, containing substances of monocyclic, diphenyl, and even higher rings simultaneously. There is a lack of data for the study of multi-component tar, especially having a substance with more than two benzene rings.

For this reason, a toluene solution of naphthalene and phenanthrene as simulated tar is used to investigate the reaction of tar compounds in the RGA reactor. Toluene, naphthalene and phenanthrene are among the dominant components of tar with one, two or three benzene rings $[25,26,37]$ so that the result in this study can match more closely to the conditions prevailing in practical application. The effects of concentrations of tar, moisture, carbon dioxide, and discharge current on destruction efficiency, energy efficiency, and main products are studied. Moreover, in order to further enhance the reaction performance, plasma catalysis, i.e., the combination of plasma with catalyst, was investigated for tar destruction, which, to the best of our knowledge, is the first attempt in gliding arc plasma used for tar destruction. $\mathrm{Ni} / \gamma-\mathrm{Al}_{2} \mathrm{O}_{3}$ catalyst was used in this study because of its proven performance for tar destruction and its merits of high mechanical strength, easy preparation, and low cost [38]. 
In the whole experiment, the total flow rate was kept at $6 \mathrm{NL} / \mathrm{min}$, the total tar concentration was kept at $12 \mathrm{~g} / \mathrm{Nm}^{3}$, and the moisture content was kept at $12 \%$ unless otherwise mentioned. Naphthalene and phenanthrene were dissolved in toluene with a mass ratio of 1:1:20.

\section{Results and Discussions}

\subsection{Effect of Tar Concentration}

The effect of tar concentration on the destruction efficiency is presented in Figure 1. A destruction efficiency of $94.3 \%$ for toluene, $87 \%$ for naphthalene, and $83.5 \%$ for phenanthrene is obtained under a total flow rate of $12 \mathrm{NL} / \mathrm{min}$, moisture concentration of $12 \%$, and tar concentration of $12 \mathrm{~g} / \mathrm{Nm}^{3}$, yielding an energy efficiency of $10.2 \mathrm{~g} / \mathrm{kW} \cdot \mathrm{h}$. The destruction efficiency decreases remarkably when tar concentration is over $16 \mathrm{~g} / \mathrm{Nm}^{3}$, in contrast to our previous study of toluene and naphthalene (without phenanthrene) destruction, where the destruction efficiency has a high value at a tar concentration of $20 \mathrm{~g} / \mathrm{Nm}^{3}$. This is because, as the experiment shows, phenanthrene addition tends to cause frequent breaking of the gliding arc, especially when both tar and moisture concentrations are high. Although the arc can be regenerated, the breaking decreases the destruction efficiency.

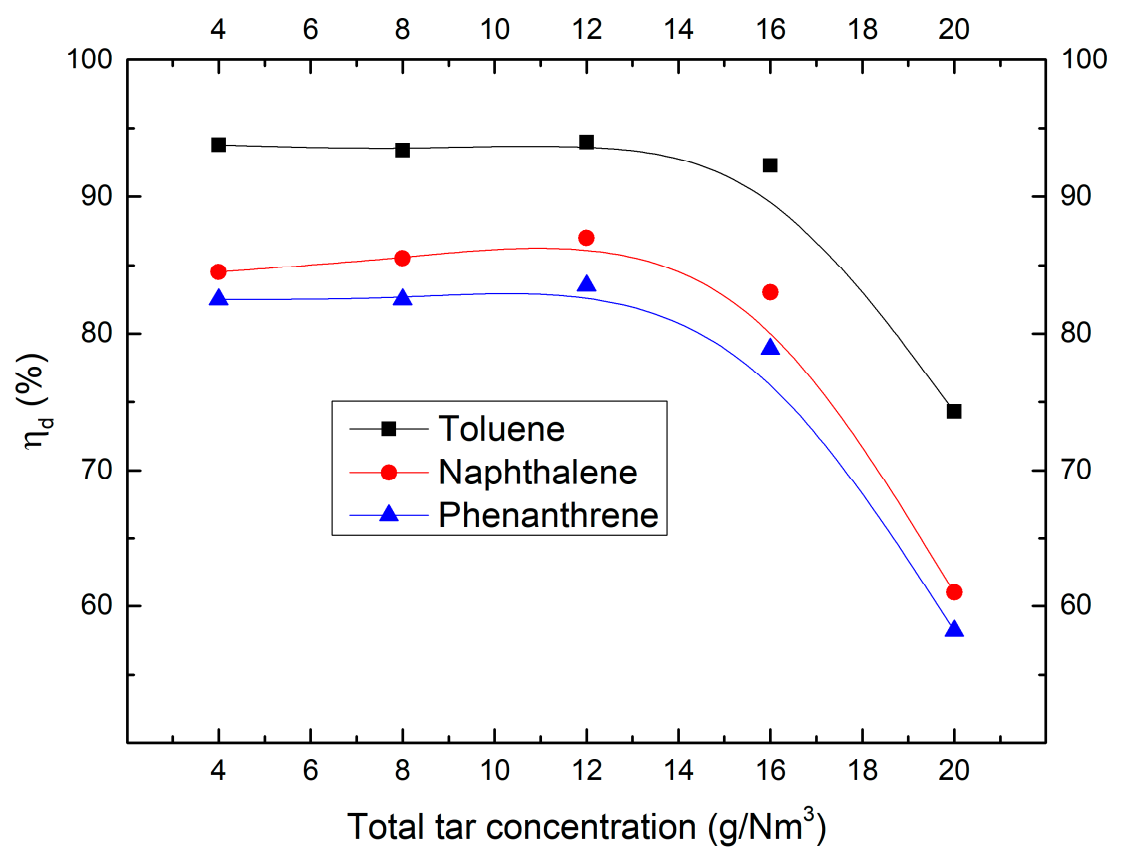

Figure 1. Effect of tar concentration on the destruction efficiency.

The order of destruction efficiency of the three components is consistently $\eta$ (toluene) $>$ $\eta$ (Naphthalene) $>\eta$ (Phenanthrene). The result that $\eta$ (toluene) $>\eta$ (Naphthalene) is in line with the results of Zhu et al. [14] and Nunnally et al. by gliding arc [15]. In the simulation work by Fourcault et al., similar results were also obtained in a plasma torch [16]. The order of activation energy of the three component is phenanthrene $>$ naphthalene $>$ toluene, explaining why a substance with more benzene rings is hard to destroy.

Figure 2 shows that the energy efficiency increases as the total tar concentration increases until reaching $16 \mathrm{~g} / \mathrm{Nm}^{3}$, after which the efficiency started decreasing. The instability of the reactor caused by the addition of phenanthrene is probably the factor that limits the maximum energy efficiency to $13 \mathrm{~g} / \mathrm{kW} \cdot \mathrm{h}$. The selectivity of $\mathrm{C}_{2} \mathrm{H}_{2}$ and $\mathrm{CO}$ rises monotonously with increasing tar concentration, while the selectivity of $\mathrm{CO}_{2}$ drops (Figure 3), though the absolute production of them as well as of $\mathrm{H}_{2}$ increases significantly as the tar concentration increases (Figure 4). The reason for this can be explained by water-gas shift reaction (Equation (1)) and reforming reaction of $\mathrm{C}_{2} \mathrm{H}_{2}$ (Equation (2)). The increase 
of tar concentration leads to the increase of $\mathrm{CO}$ and $\mathrm{C}_{2} \mathrm{H}_{2}$. The increase of $\mathrm{CO}$ and $\mathrm{C}_{2} \mathrm{H}_{2}$ promote the positive reaction of water-gas shifting and reforming reaction respectively, which increases the production of all the gas products. However, the concentration of $\mathrm{H}_{2} \mathrm{O}$ is constant, which limits the conversion rate of $\mathrm{CO}$ and $\mathrm{C}_{2} \mathrm{H}_{2}$ in the case of high tar concentration, leading to a high selectivity of $\mathrm{CO}$ and $\mathrm{C}_{2} \mathrm{H}_{2}$ while lowering the selectivity of $\mathrm{CO}_{2}$.

$$
\begin{gathered}
\mathrm{CO}+\mathrm{H}_{2} \mathrm{O} \rightarrow \mathrm{CO}_{2}+\mathrm{H}_{2} \\
\mathrm{C}_{2} \mathrm{H}_{2}+2 \mathrm{H}_{2} \mathrm{O} \rightarrow 2 \mathrm{CO}+3 \mathrm{H}_{2}
\end{gathered}
$$

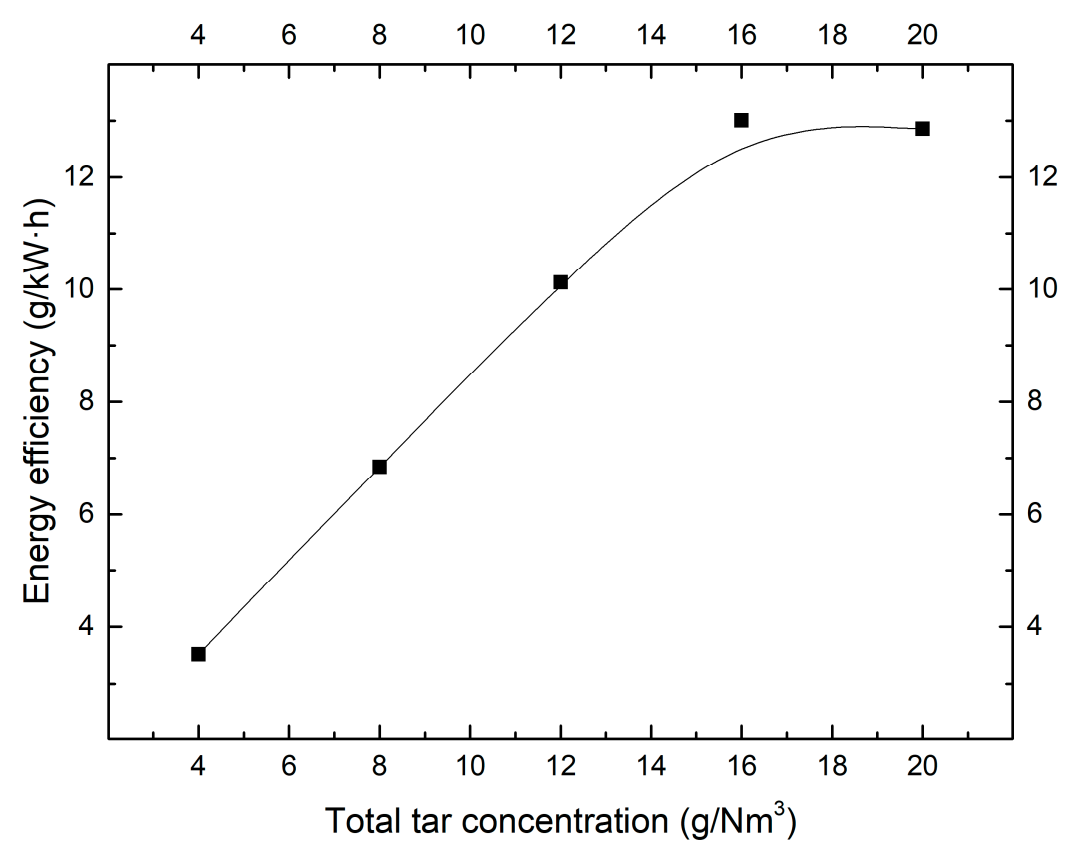

Figure 2. Effect of $f$ tar concentration on the energy efficiency.

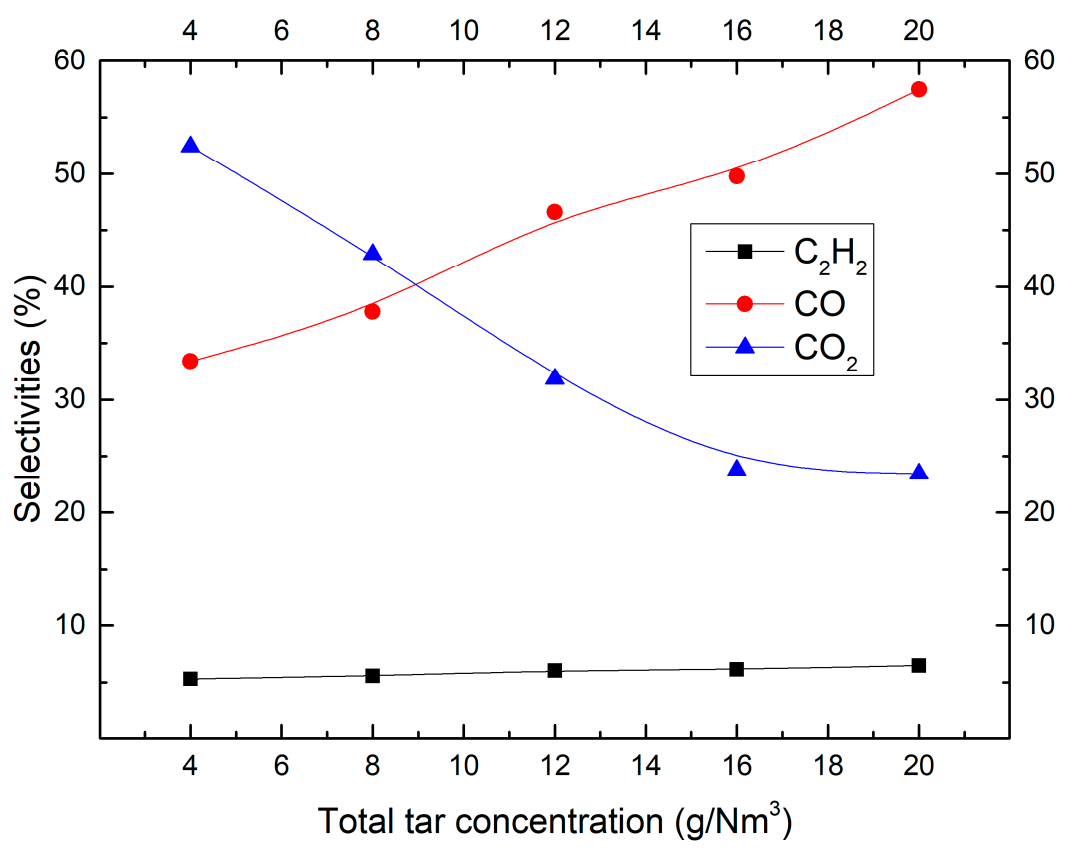

Figure 3. Effect of tar concentration on the selectivity of $\mathrm{CO}, \mathrm{CO}_{2}$ and $\mathrm{C}_{2} \mathrm{H}_{2}$. 


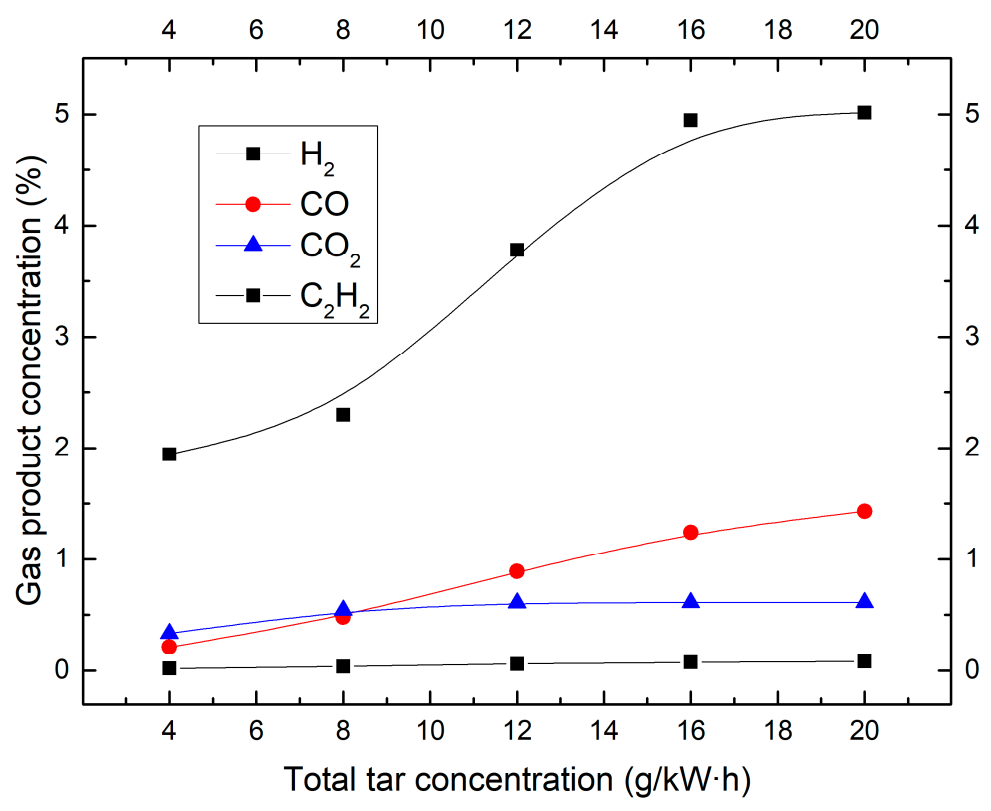

Figure 4. Effect of tar concentration on the composition of the off-gas.

\subsection{Effect of Moisture Content}

Figure 5 indicates that as the moisture concentration increases, the destruction efficiency of toluene, naphthalene, and phenanthrene increases first to a maximum at a moisture concentration of $8 \%$ or $12 \%$ and then starts decreasing. Previous studies by Zhu et al. [36] and Chun et al. [39] showed a similar phenomenon for the decomposition of tar surrogate using gliding arc. The proper amount of moisture facilitates the reaction because of the generation of $\mathrm{OH}$ radicals [40], while too much water has an adverse effect on tar destruction due to its electronegative characteristics, which limits electron density and quenches reactive species [30]. When the moisture concentration is up to $20 \%$, the destruction efficiency declines suddenly because high concentration of moisture makes the reactor unsteady due to the existence of a high concentration of phenanthrene. The energy efficiency decreases linearly as the moisture concentration increases, as shown in Figure 6.

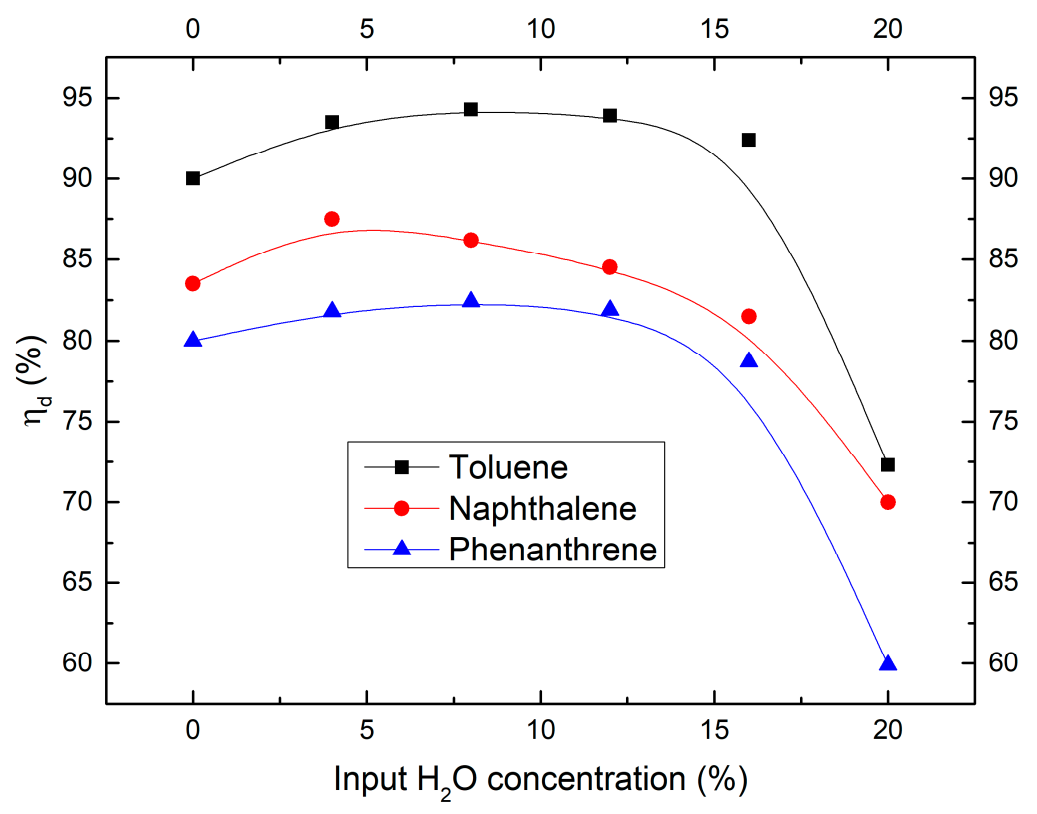

Figure 5. Effect of moisture concentration on destruction efficiency. 


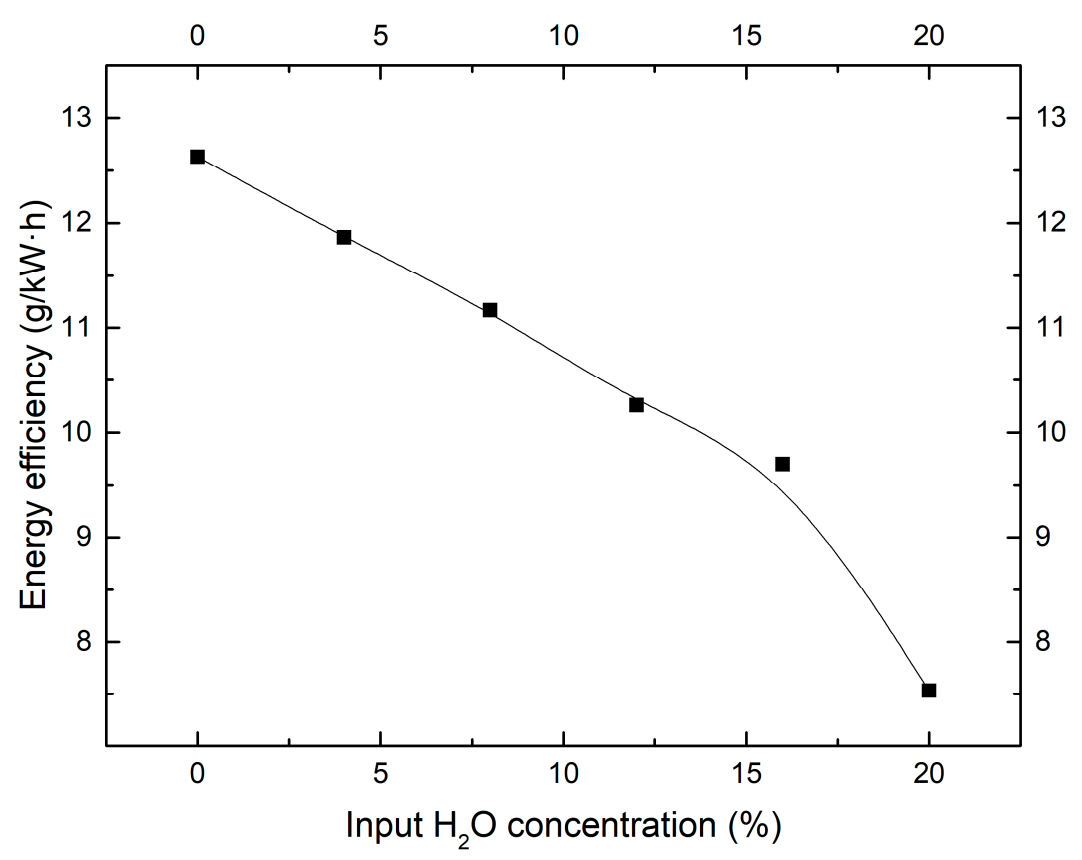

Figure 6. Effect of moisture concentration on energy efficiency.

As Figure 7 presents, the selectivity of $\mathrm{CO}$ and $\mathrm{CO}_{2}$ increases with the increase of the moisture concentration, while the selectivity of $\mathrm{C}_{2} \mathrm{H}_{2}$ decreases because water brings oxygen to the reaction. The selectivity of $\mathrm{CO}, \mathrm{CO}_{2}$, and $\mathrm{C}_{2} \mathrm{H}_{2}$ can be over $80 \%$ in total if enough water molecules are provided, and reach a maximum of $95 \%$ at a moisture concentration of $20 \%$. However, the selectivity of $\mathrm{C}_{2} \mathrm{H}_{2}$ is $13 \%$ and selectivity of $\mathrm{CO}$ and $\mathrm{CO}_{2}$ is 0 under the dry conditions, which means most of the carbon element turns into black carbon in water deficient conditions. In addition, the increase of moisture concentration raises the hydrogen production remarkably, as presented in Figure 8. It is interesting to note that proper concentration can turn the production of solid carbon into gas, especially flammable gas like $\mathrm{H}_{2}$ and $\mathrm{CO}$, which are highly desirable.

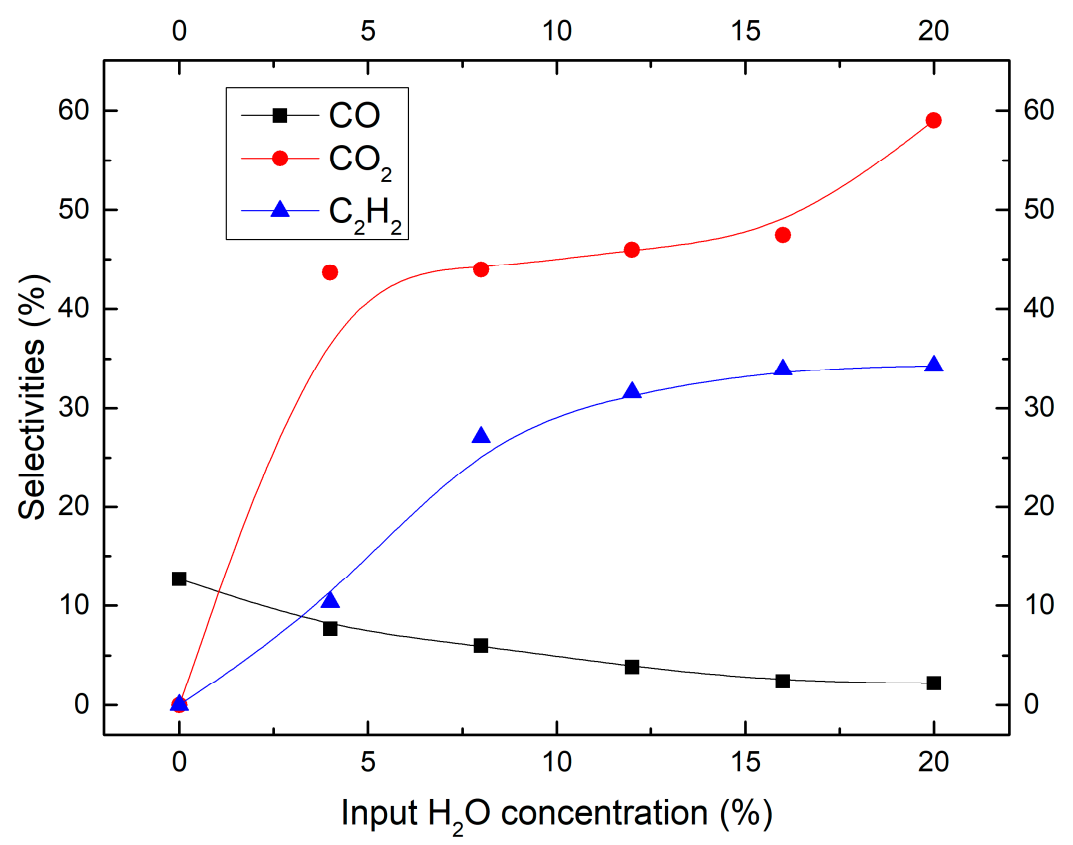

Figure 7. Effect of moisture concentration on the selectivity of $\mathrm{CO}, \mathrm{CO}_{2}, \mathrm{C}_{2} \mathrm{H}_{2}$. 


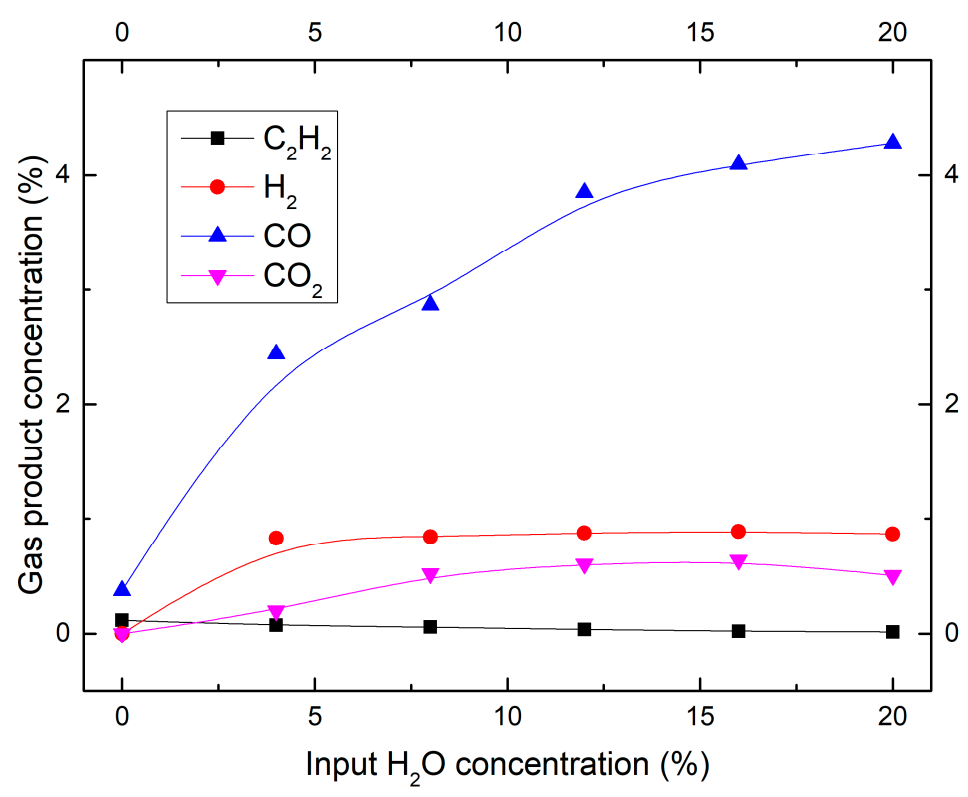

Figure 8. Effect of moisture concentration on the composition of the off-gas.

\subsection{Effect of $\mathrm{CO}_{2}$ Concentration}

Figure 9 shows that with increasing $\mathrm{CO}_{2}$ concentration, the destruction efficiency of the toluene, naphthalene, and phenanthrene increases to a maximum at an input of $15 \% \mathrm{CO}_{2}$ concentration, and then slightly reduced. Uncommon voltage waveform was observed under the condition with proper concentration of $\mathrm{CO}_{2}$, which can explain why the highest destruction efficiency is obtained in the atmosphere of $15 \% \mathrm{CO}_{2}$. The voltage waveform is shown in Figure 10 under the condition with or without $\mathrm{CO}_{2}$. Compared with the typical condition without $\mathrm{CO}_{2}$, the waveform becomes regular in the condition of $10 \%-20 \% \mathrm{CO}_{2}$. The voltage as well as the input energy have increased about $15 \%$ (from $1.80 \mathrm{kV}$ to $2.07 \mathrm{kV}$ of voltage), while the discharge current is the same. When the $\mathrm{CO}_{2}$ increases to about $25 \%$, the waveform of voltage again becomes similar to the waveform without $\mathrm{CO}_{2}$ and the average voltage reduces simultaneously but remains higher than that in the condition without the participation of $\mathrm{CO}_{2}$. The role of oxidation of $\mathrm{CO}_{2}$ in destruction efficiency is slightly lower compared to $\mathrm{H}_{2} \mathrm{O}$ that can provide sufficient $\mathrm{O}$ atoms.

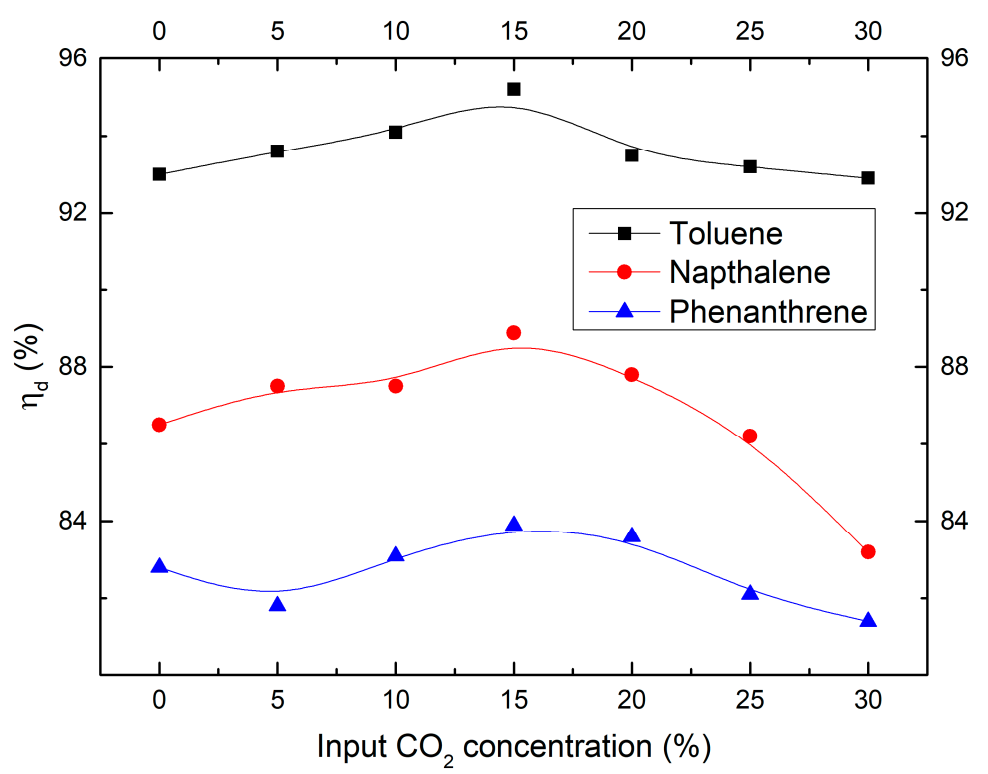

Figure 9. Effect of $\mathrm{CO}_{2}$ concentration on destruction efficiency. 


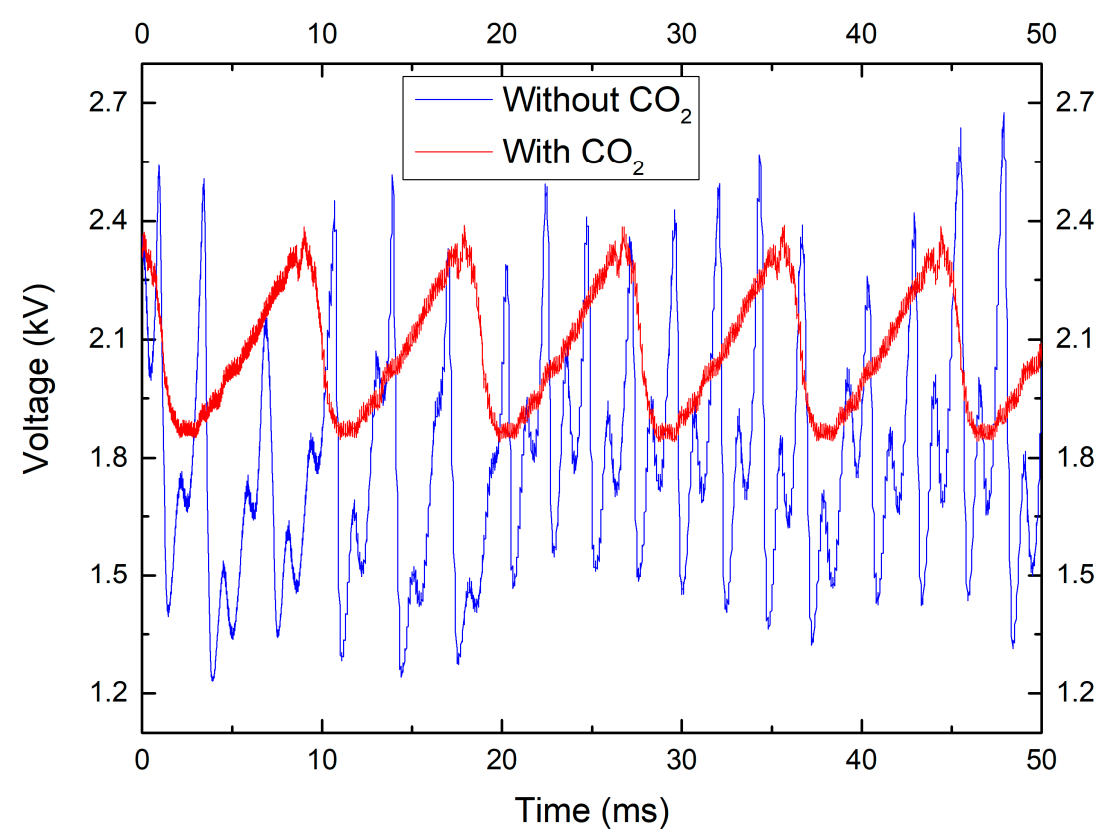

Figure 10. Voltage waveform of the discharge with $15 \% \mathrm{CO}_{2}$ and without $\mathrm{CO}_{2}$.

When the concentration of $\mathrm{CO}_{2}$ increases, the amount of $\mathrm{CO}$ in the product increases and the amount of $\mathrm{H}_{2}$ and $\mathrm{C}_{2} \mathrm{H}_{2}$ decreases because of the reverse reaction of water-gas shift reaction (Equation (1)) and the dry reforming reaction of $\mathrm{C}_{2} \mathrm{H}_{2}$ (Equation (3)). Although the components of gas production change a lot because of $\mathrm{CO}_{2}$, the heating value of the fuel after the reaction changes little because the production of $\mathrm{CO}$ increases while the production of $\mathrm{H}_{2}$ decreases. As shown in Figure 11, the negative effect of $\mathrm{CO}_{2}$ on the destruction is that it can reduce the energy efficiency of the reaction (Figure 12).

$$
\mathrm{C}_{2} \mathrm{H}_{2}+2 \mathrm{CO}_{2} \rightarrow 4 \mathrm{CO}+2 \mathrm{H}_{2}
$$

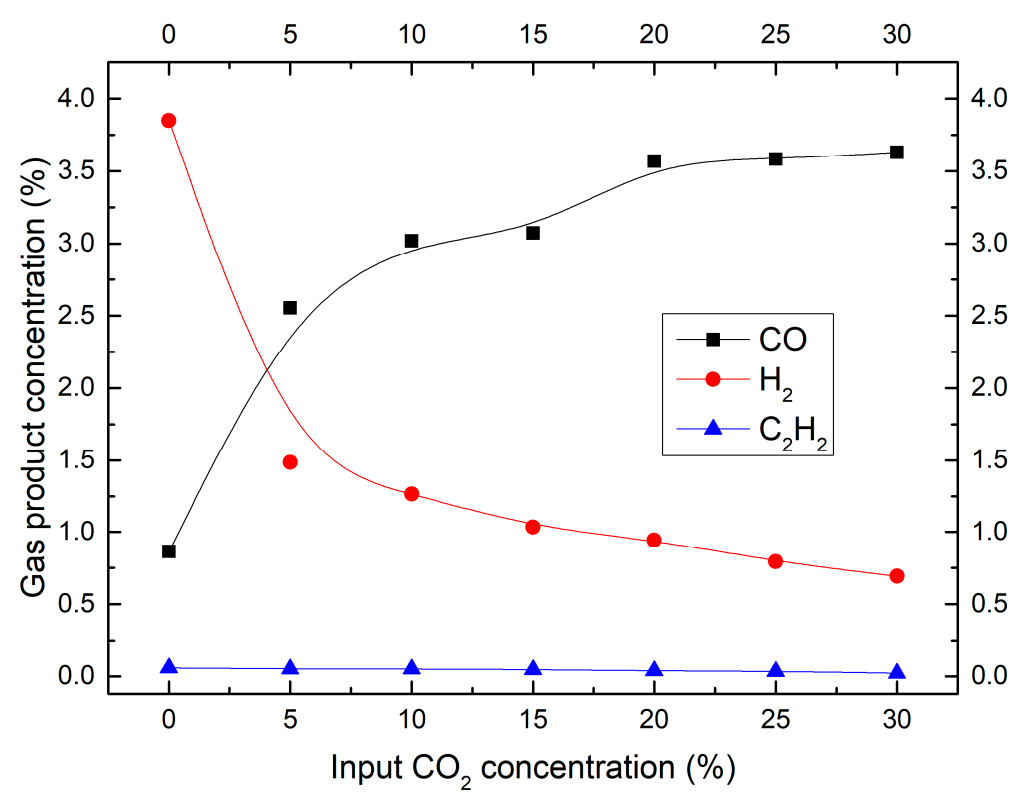

Figure 11. Effect of $\mathrm{CO}_{2}$ concentration on the composition of the off-gas. 


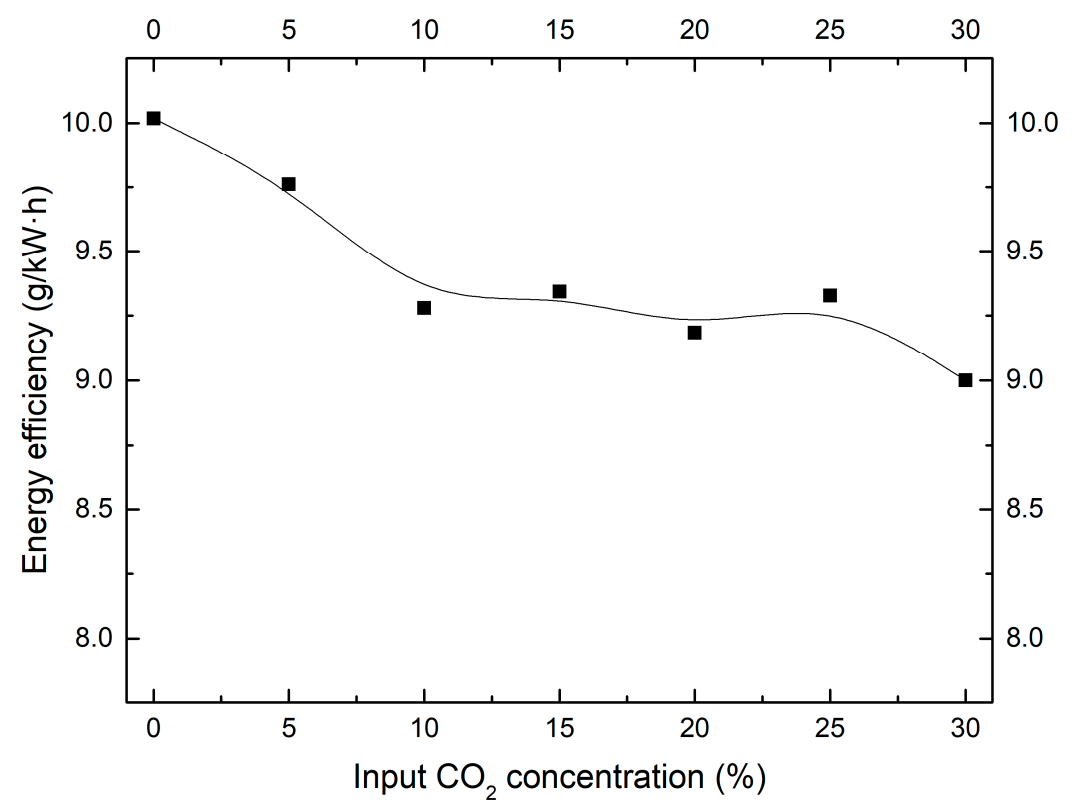

Figure 12. Effect of $\mathrm{CO}_{2}$ concentration on energy efficiency.

\subsection{Effect of Discharge Current}

As expected, with an increasing discharge current, destruction efficiency increases (Figure 13). However, compared to this slight improvement in destruction efficiency (about 3\%), decreased energy efficiency it causes is much higher (more than 10\%, as shown in Figure 14). The production of $\mathrm{H}_{2}$ and $\mathrm{CO}_{2}$ increases significantly with the increase of discharge current, which indicates that extra input of energy is probably consumed for splitting of water as discharge current rises (Figure 15). The total selectivity of carbon-contained gases $\left(\mathrm{CO}, \mathrm{CO}_{2}\right.$ and $\left.\mathrm{C}_{2} \mathrm{H}_{2}\right)$ increases from $80 \%$ to $88 \%$ as the discharge current increases from $200 \mathrm{~mA}$ to $250 \mathrm{~mA}$ (Figure 16), which means increasing discharge current reduces about half of the production of solid carbon. This result is desirable to achieve maximum conversion of carbon to gas components.

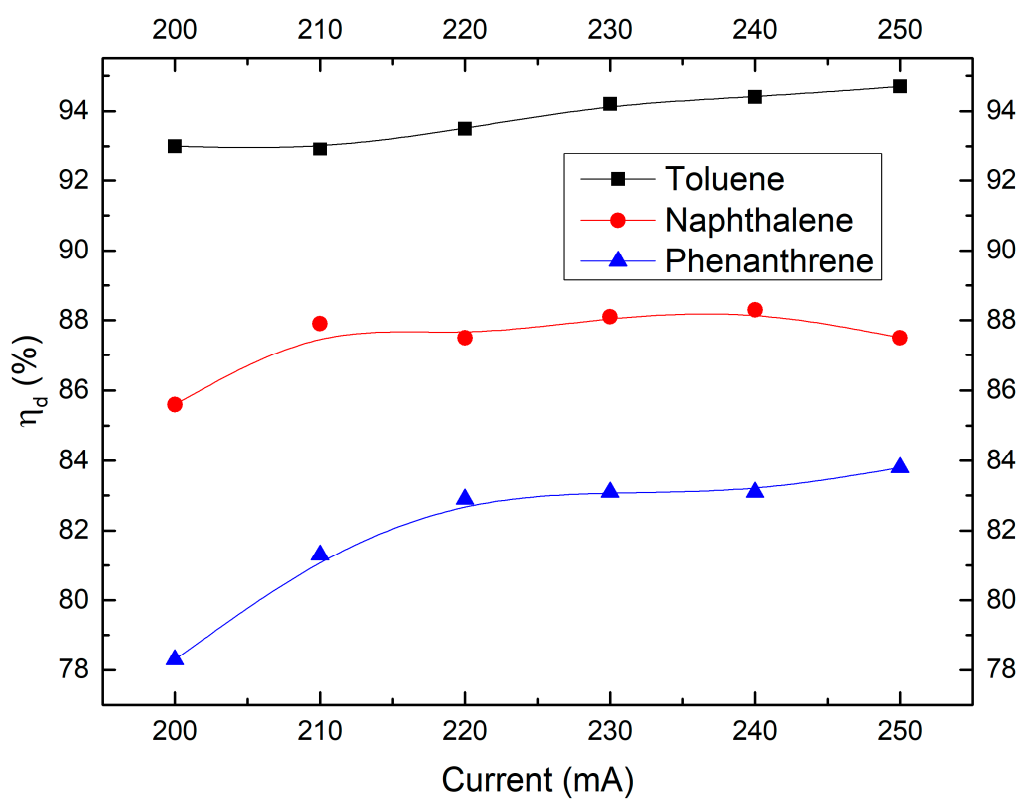

Figure 13. Effect of discharge current on destruction efficiency. 


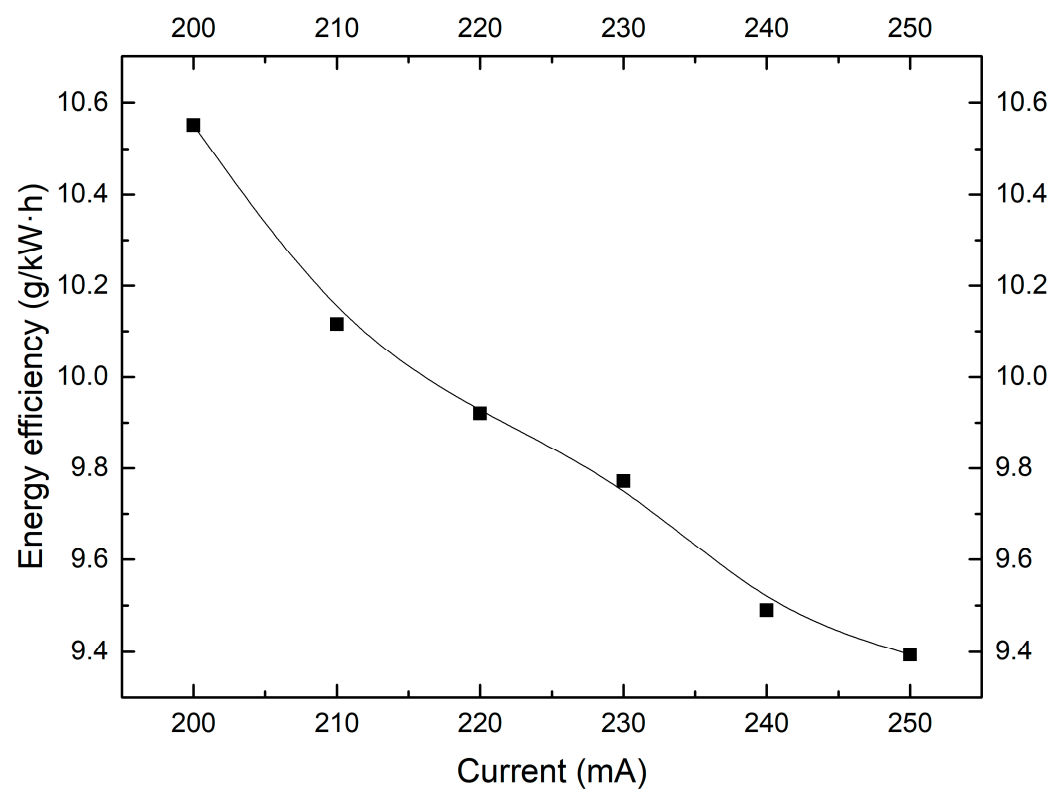

Figure 14. Effect of discharge current on the energy efficiency.

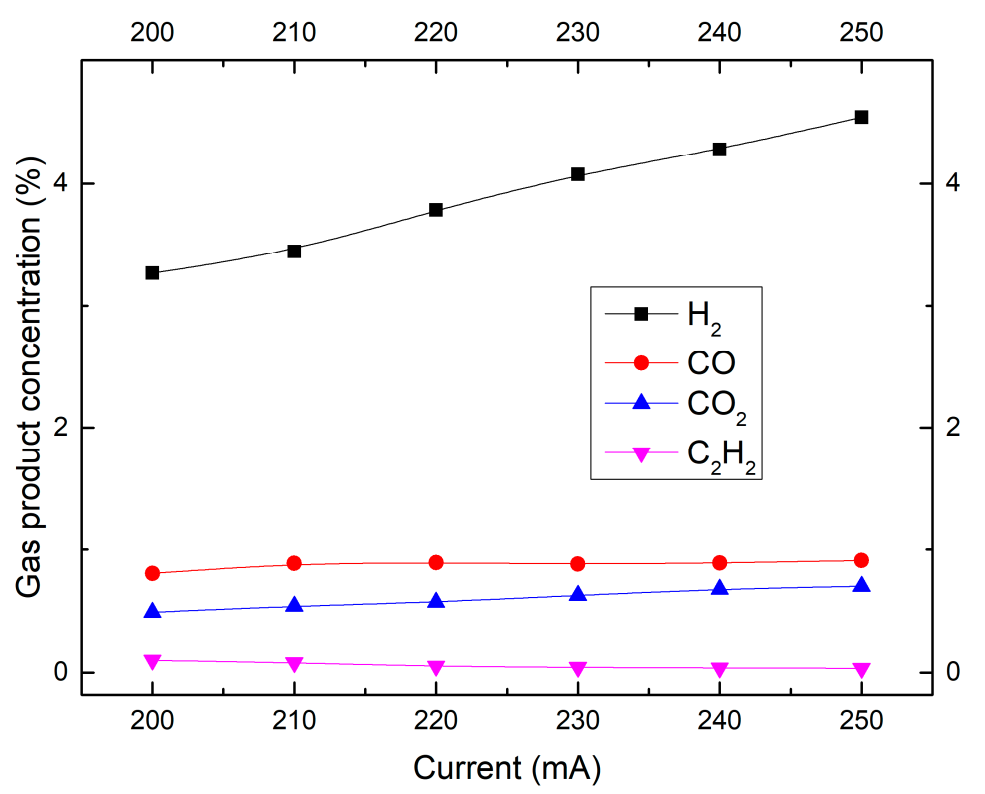

Figure 15. Effect of discharge current on the composition of the off-gas. 


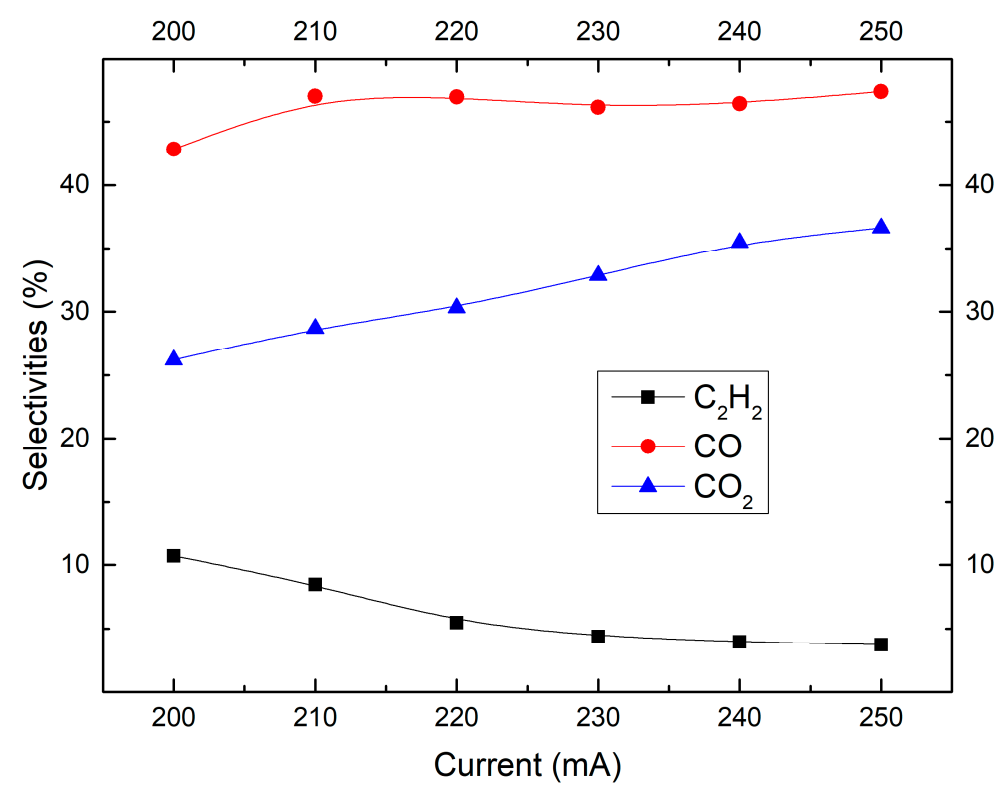

Figure 16. Effect of discharge current on the selectivity of $\mathrm{C}_{2} \mathrm{H}_{2}, \mathrm{CO}$ and $\mathrm{CO}_{2}$.

SEI goes up as the discharge current goes up, but less pronouncedly, because the voltage of the reactor decreases with increase of discharge current. The discharge current increases $25 \%$ (from $200 \mathrm{~mA}$ to $250 \mathrm{~mA}$ ) while the SEI increases about $13 \%$ (from about $1.05 \mathrm{~kW} \cdot \mathrm{h} / \mathrm{m}^{3}$ to about $1.20 \mathrm{~kW} \cdot \mathrm{h} / \mathrm{m}^{3}$, as shown in Figure 17).

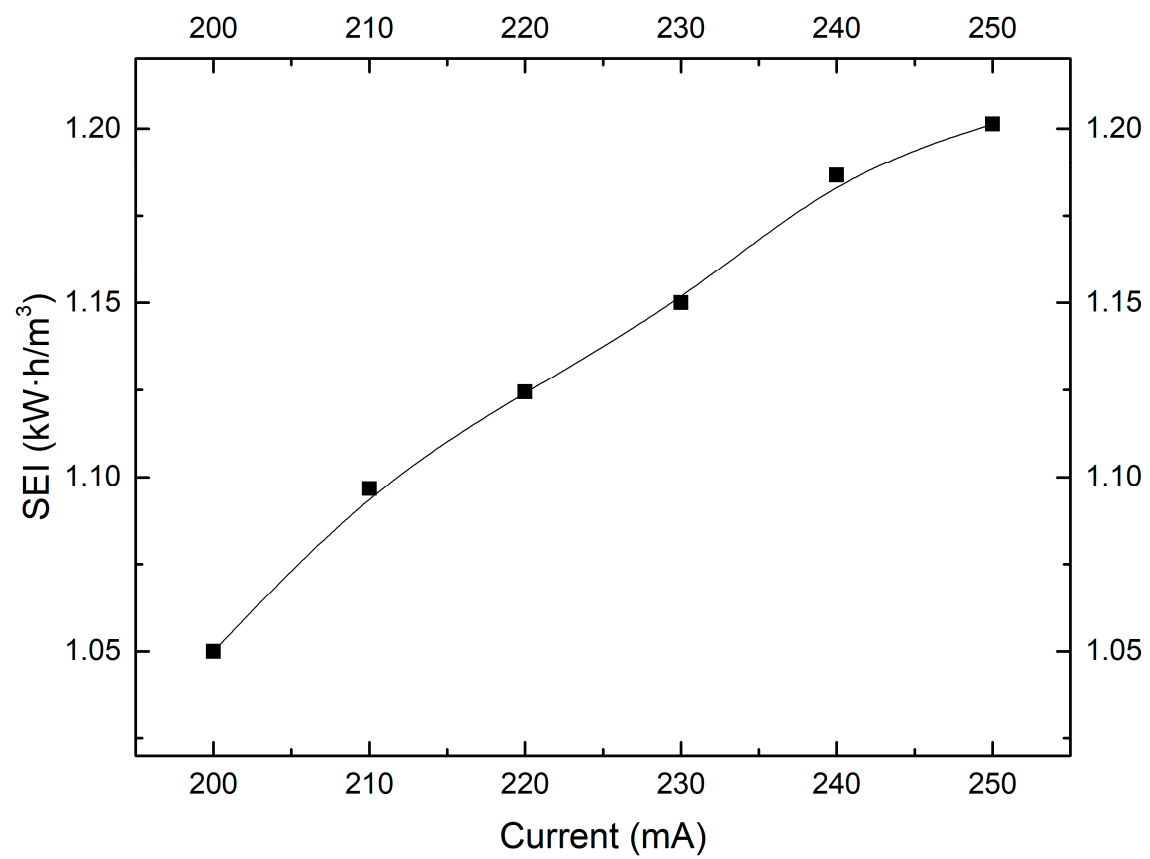

Figure 17. Effect of discharge current on specific energy input (SEI).

\subsection{Effect of the Coupling of Catalyst with Plasma}

In this section, the influence of catalyst in the reaction is investigated under different flow rates. A tray containing catalyst is placed downstream the plasma area, i.e., $18 \mathrm{~mm}$ under the anode. In this distance the rotating gliding arc can just touch the catalyst surface. The diameter of the spherical catalyst particles is $2 \mathrm{~mm}$. Tar and moisture concentration were fixed as $12 \mathrm{~g} / \mathrm{Nm}^{3}$ and $12 \%$ respectively. 
To understand whether the performance variation in the experiment is caused by the catalysis or flow field, comparative experiments have been performed with glass beads on the tray.

Figure 18 illustrates the influence of catalyst on destruction efficiency under different flow rates. The catalyst has little effect when the flow rate is relatively low $(6 \mathrm{NL} / \mathrm{min})$, as shown in Figure 18a. This is possibly because the destruction efficiency of plasma alone is so high that the amount of remaining tar is too low to involve in catalytic reaction. However, the catalyst reflects to be effective and improves the destruction efficiency remarkably under the flow rate of $9 \mathrm{NL} / \mathrm{min}$ and $12 \mathrm{NL} / \mathrm{min}$. For instance, for a flow rate of $12 \mathrm{NL} / \mathrm{min}$, the destruction efficiency of toluene, naphthalene, and phenanthrene increases to $90 \%, 86 \%$, and $76 \%$ respectively, with the presence of the catalyst in the tray, from $85 \%, 80 \%$, and $70 \%$ respectively with only glass beads in the tray (Figure 18c). The destruction efficiency in the condition of glass beads in the reactor is similar to that without a tray in the reactor according to Figure 18a-c, which indicates that the flow field changed by the tray contributes little to the change of destruction efficiency. In addition, the catalyst increases the energy efficiency when the flow rate is high, especially at a flow rate of $12 \mathrm{~L} / \mathrm{min}$, from $19.1 \mathrm{~g} / \mathrm{kW} \cdot \mathrm{h}$ to $21.3 \mathrm{~g} / \mathrm{kW} \cdot \mathrm{h}$ (Figure 19). As shown in Figure 20, the catalyst increases the production of gas products as well as destruction efficiency, indicating that the tar is definitely destroyed instead of being absorbed on the catalyst. The result illustrates that the $\mathrm{Ni} / \gamma-\mathrm{Al}_{2} \mathrm{O}_{3}$ catalyst can be highly effective when single plasma cannot reduce the tar concentration to an ideal standard. As a result, plasma coupled with catalyst is worth using when the flow rate is high. It should be noted that a slight carbon deposition was observed on the catalyst after an operation of $1.5 \mathrm{~h}$, which should be considered in the application of plasma catalysis.
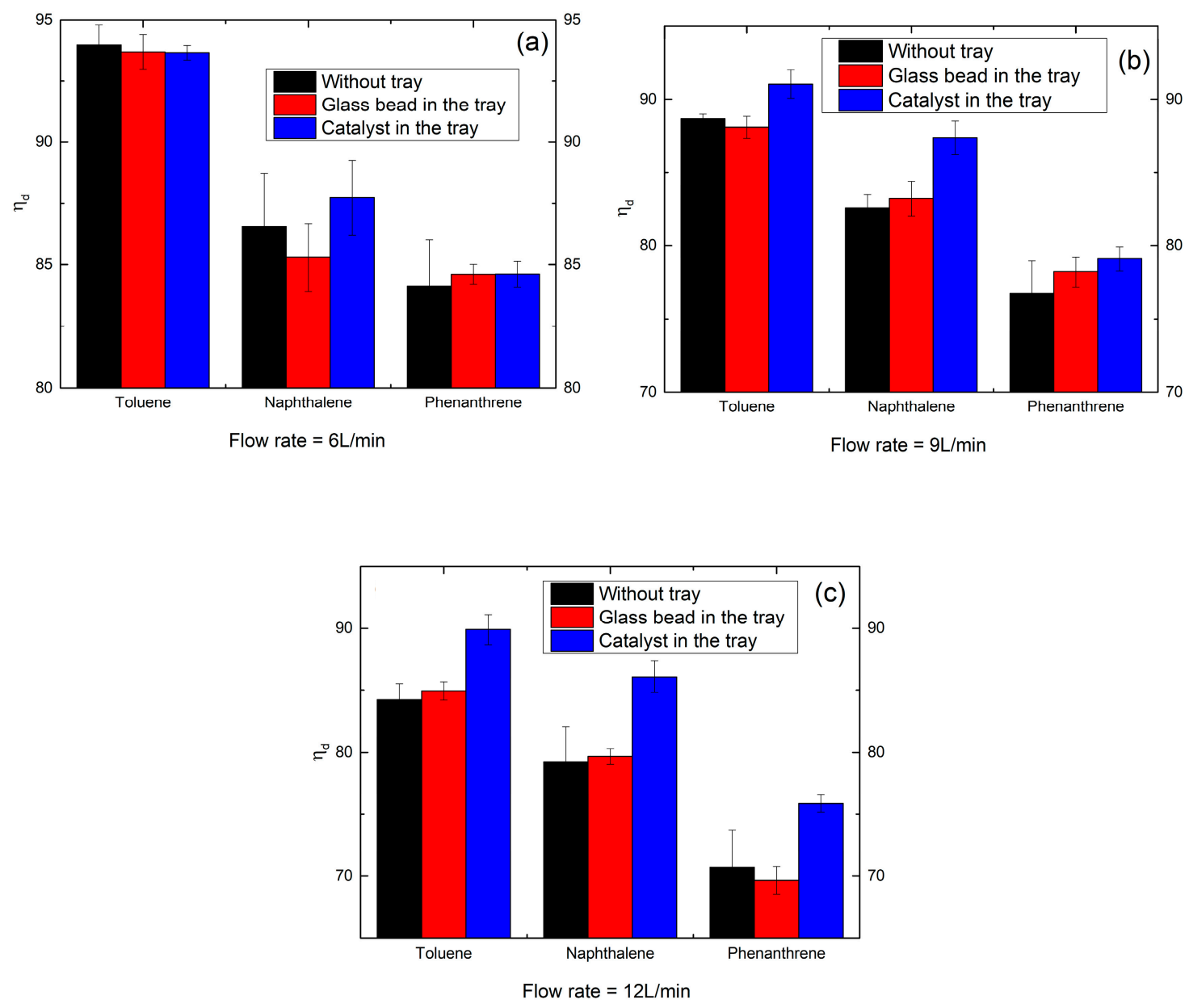

Figure 18. Effect of catalyst on destruction efficiency at flow rates of (a) $6 \mathrm{NL} / \mathrm{min}$, (b) $9 \mathrm{NL} / \mathrm{min}$ and (c) $12 \mathrm{NL} / \mathrm{min}$. 


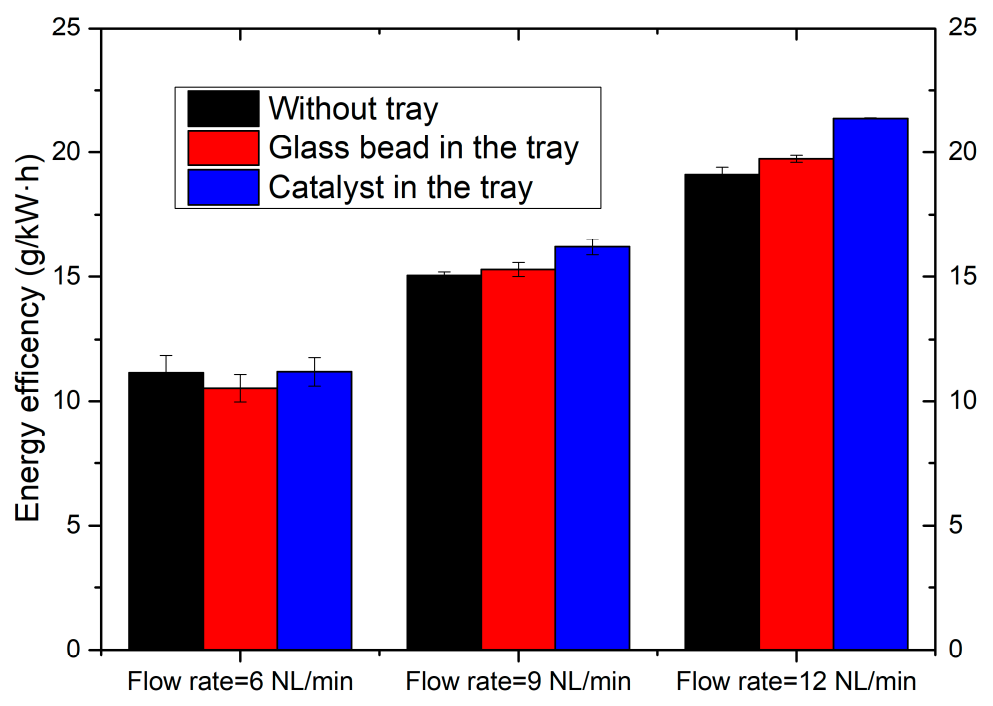

Figure 19. Effect of catalyst on energy efficiency at flow rates of $6 \mathrm{NL} / \mathrm{min}, 9 \mathrm{NL} / \mathrm{min}$ and $12 \mathrm{NL} / \mathrm{min}$.

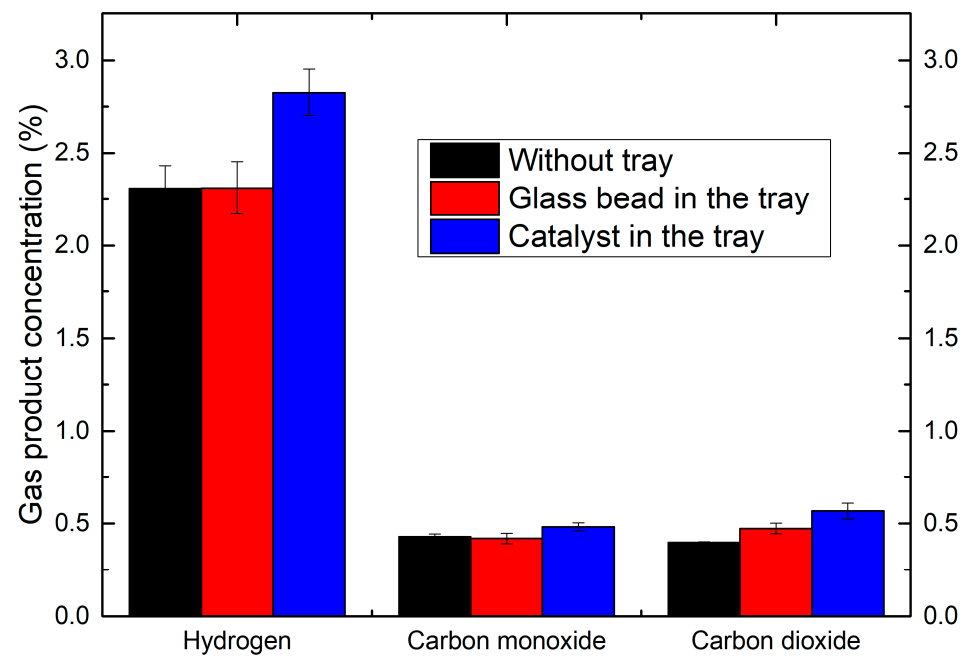

Figure 20. Effect of catalyst on the composition of the off-gas at a flow rate of $12 \mathrm{NL} / \mathrm{min}$.

\subsection{Liquid By-Products Analysis}

To investigate the reaction mechanisms in the destruction of toluene, naphthalene, and phenanthrene together, liquid by-products collected in the absorption bottle were analyzed using GC/MS. Results in two working conditions are presented in this section. The first one is the typical working condition (a total flow rate of $6 \mathrm{NL} / \mathrm{min}$, tar concentration of $12 \mathrm{~g} / \mathrm{Nm}^{3}$, and moisture concentration of $12 \%$ ), and the second one is similar to the first but there is $15 \% \mathrm{CO}_{2}$ in the atmosphere, occupying the content of nitrogen. The composition of the two liquid products have some differences, as shown in Table 1. The corresponding product structures are schematically shown in Table 2.

The major by-products are phenylethyne, indene, acenaphthylene, and fluoranthene, according to the full scan GC/MS result presented in Table 1, irrespective of the presence or absence of $\mathrm{CO}_{2}$ in the atmosphere. Among the four major products, phenylethyne and indene were also found in by-products in the previous study of single toluene destruction by gliding arc [8], which indicates that these are probably majorly converted from toluene. The possible reaction pathway is shown in Equations (4)-(10) [22,24]. The yield of acenaphthylene in the previous study of single toluene or single naphthalene destruction by gliding arc was far lower $[8,41]$, compared with present work with very high efficiency of naphthalene toluene solution destruction, which means naphthalene and toluene are both involved in the reaction of acenaphthylene production. 
Table 1. Liquid by-products detected by GC/MS (in typical atmosphere with or without $\mathrm{CO}_{2}$ ).

\begin{tabular}{ccccc}
\hline No & $\begin{array}{c}\text { Retention } \\
\text { Time (min) }\end{array}$ & Species & $\begin{array}{c}\text { Area Percentage (\%, the } \\
\text { Area Percent of Input } \\
\text { Naphthalene is 1000) } \\
\text { under Typical } \\
\text { Atmosphere }\end{array}$ & $\begin{array}{c}\text { Area Percentage (\%, } \\
\text { the Area Percent of } \\
\text { Input Naphthalene is } \\
\text { 1000\%) when 15\% } \\
\text { CO }_{2} \text { Exists }\end{array}$ \\
\hline 1 & & Ethylbenzene & 0.9 & 0.9 \\
2 & 6.590 & Phenylethyne & 17.2 & 15.3 \\
3 & 7.109 & Styrene & 0.7 & 1 \\
4 & 8.222 & Benzaldehyde & $<0.1$ & 0.7 \\
5 & 8.477 & Phenol & $<0.1$ & 0.4 \\
6 & 8.572 & Benzonitrile & 0.7 & 0.8 \\
7 & 9.383 & Indene & 11.3 & 16 \\
8 & 9.685 & Phenol, 2-methyl- & $<0.1$ & 0.3 \\
9 & 11.791 & Cyclobuta[de]naphthalene & 0.9 & 1.1 \\
10 & 12.085 & Naphthalene, 2-methyl- & 1.1 & 1.3 \\
11 & 12.240 & Naphthalene, 1-methyl- & 0.7 & 1.3 \\
12 & 12.538 & Benzene, 2,4-pentadiynyl- & 0.2 & 0.7 \\
13 & 12.775 & Biphenyl & 1.3 & 1.2 \\
14 & 13.354 & Acenaphthylene & 39.8 & 16.2 \\
15 & 13.813 & Bibenzyl & 0.4 & 1.7 \\
16 & 14.269 & Fluorene & 27.9 & 23.4 \\
17 & 16.040 & 4H-Cyclopenta[def]phenanthrene & 1.0 & 0.9 \\
18 & 16.622 & Fluoranthene & 2.9 & 1.1 \\
19 & 16.847 & Pyrene & 5.9 & 1.1 \\
\hline
\end{tabular}

The feasible way is shown in Equations (7), (11), and (12). In the case of fluoranthene, it is not detected by the GC/MS when phenanthrene was not involved in previous study, indicating that it is converted from phenanthrene. The molecular structure of this substance also corresponds to this speculation. The conversion of phenanthrene to fluoranthene is a vital reaction, as the area percentage of fluoranthene is up to $15 \%$ compared with unreacted phenanthrene. The feasible way is shown in Equations (13) and (14).

$$
\begin{aligned}
& \mathrm{C}_{6} \mathrm{H}_{5} \mathrm{CH}_{3}+\mathrm{N}_{2}{ }^{*} \rightarrow \mathrm{C}_{6} \mathrm{H}_{5} \mathrm{CH}_{2}+\mathrm{H}+\mathrm{N}_{2} \\
& \mathrm{C}_{6} \mathrm{H}_{5} \mathrm{CH}_{3}+\mathrm{N}_{2}{ }^{*} \rightarrow \mathrm{C}_{6} \mathrm{H}_{4} \mathrm{CH}_{3}+\mathrm{H}+\mathrm{N}_{2} \\
& \mathrm{C}_{6} \mathrm{H}_{5} \mathrm{CH}_{3}+\mathrm{N}_{2}{ }^{*} \rightarrow \mathrm{C}_{6} \mathrm{H}_{5}+\mathrm{CH}_{3}+\mathrm{N}_{2} \\
& \mathrm{C}_{6} \mathrm{H}_{5} \mathrm{CH}_{3}+\mathrm{N}_{2}{ }^{*} \rightarrow \mathrm{C}_{5} \mathrm{H}_{6}+\mathrm{C}_{2} \mathrm{H}_{2}+\mathrm{N}_{2} \\
& \mathrm{C}_{6} \mathrm{H}_{5}+\mathrm{C}_{2} \mathrm{H}_{2} \rightarrow \mathrm{C}_{6} \mathrm{H}_{5} \mathrm{C}_{2} \mathrm{H} \text { (Phenylethyne) }+\mathrm{H} \\
& \mathrm{C}_{6} \mathrm{H}_{5} \mathrm{CH}_{2}+\mathrm{C}_{2} \mathrm{H}_{2} \rightarrow \mathrm{C}_{6} \mathrm{H}_{4} \mathrm{C}_{3} \mathrm{H}_{4} \text { (Indene) } \\
& \mathrm{C}_{6} \mathrm{H}_{4} \mathrm{CH}_{3}+\mathrm{C}_{2} \mathrm{H}_{2} \rightarrow \mathrm{C}_{6} \mathrm{H}_{4} \mathrm{C}_{3} \mathrm{H}_{4} \text { (Indene) } \\
& \mathrm{C}_{10} \mathrm{H}_{8} \text { (Naphthalene) }+\mathrm{N}_{2}{ }^{*} \rightarrow \mathrm{C}_{10} \mathrm{H}_{7}+\mathrm{H}+\mathrm{N}_{2} \\
& \mathrm{C}_{10} \mathrm{H}_{7}+\mathrm{C}_{2} \mathrm{H}_{2} \rightarrow \mathrm{C}_{12} \mathrm{H}_{10} \text { (Acenaphthylene) }+\mathrm{H} \\
& \mathrm{C}_{14} \mathrm{H}_{10} \text { (phenanthrene) }+\mathrm{N}_{2}{ }^{*} \rightarrow \mathrm{C}_{13} \mathrm{H}_{9}+\mathrm{CH}+\mathrm{N}_{2} \\
& \mathrm{C}_{13} \mathrm{H}_{9}+\mathrm{H} \rightarrow \mathrm{C}_{13} \mathrm{H}_{10} \text { (Fluorene) }
\end{aligned}
$$

As shown in Table 2, the main difference in products under two working conditions is the content of oxygen-containing by-products (e.g., benzaldehyde, phenol, 2-methyl-) when $\mathrm{CO}_{2}$ is involved in the reaction compared with no participation of $\mathrm{CO}_{2}$. This is because $\mathrm{CO}_{2}$ provides an oxygen element, which is easy to react.

It should be noted that there must be anthracene in the by-product, but the detection of it is interfered as the phenanthrene is not completely pure (95\% purity) and most of the impurity in it is 
anthracene according to the GC/MS result of blank test. Despite this, the impurity in phenanthrene is not high enough to influence other results discussed in this paper. Moreover, the quantity of by-products heavier than phenanthrene molecules do not reach a level worth mentioning.

Previous study indicates that the destruction of naphthalene in this reactor can produce phenylethyne. Therefore, it is expected that the partial cracking of phenanthrene can also lead to the formation of bicyclic or even monocyclic products.

Table 2. Relevant liquid by-product structures.

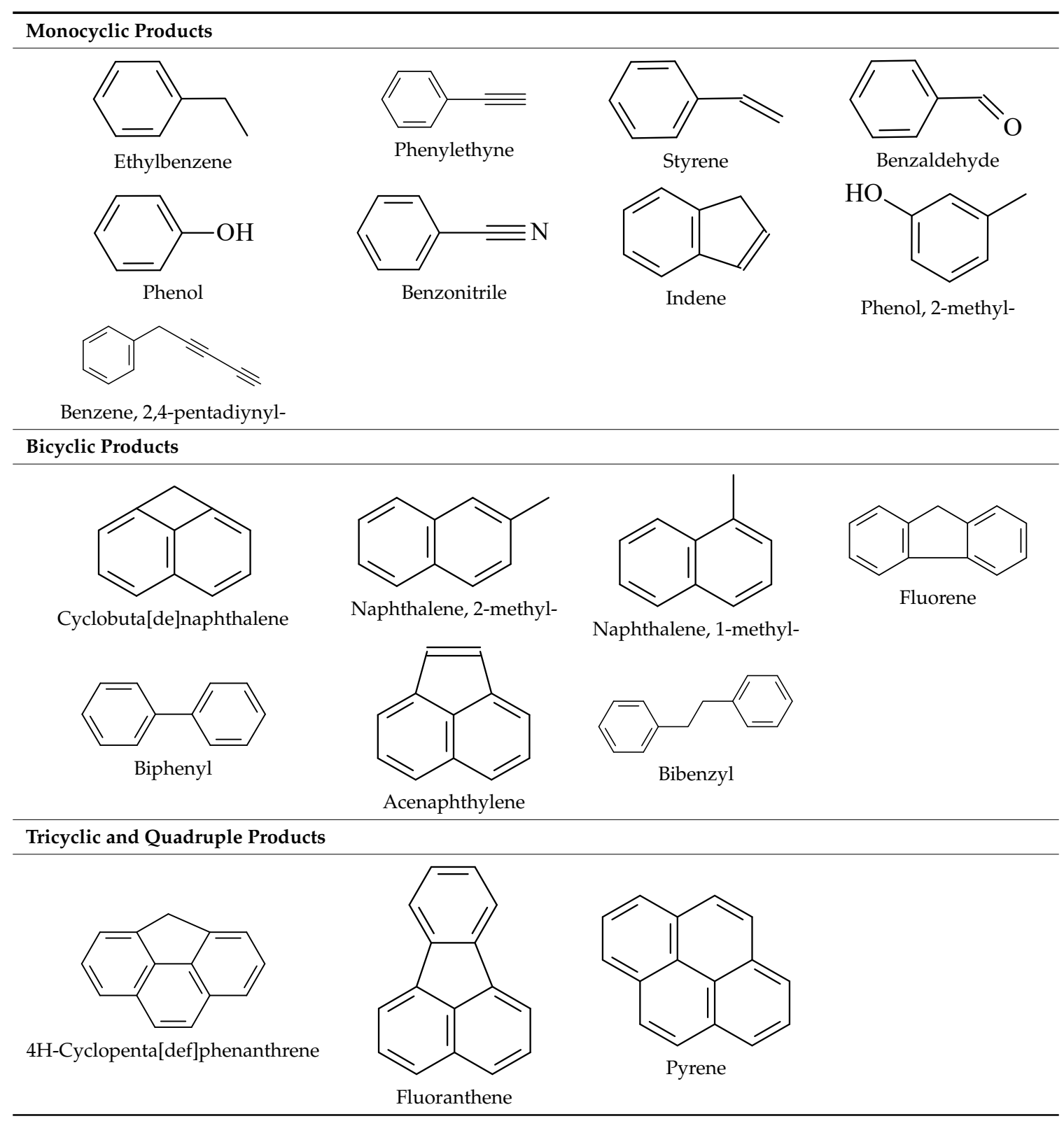

\section{Experimental}

\subsection{Experimental Setup}

Figure 21 schematically shows the rotating gliding arc (RGA) experimental setup for model tar destruction. The whole system consists of 4 parts: The Feeding System, the Reactor System, the Circuit System, and the Measurement System. 


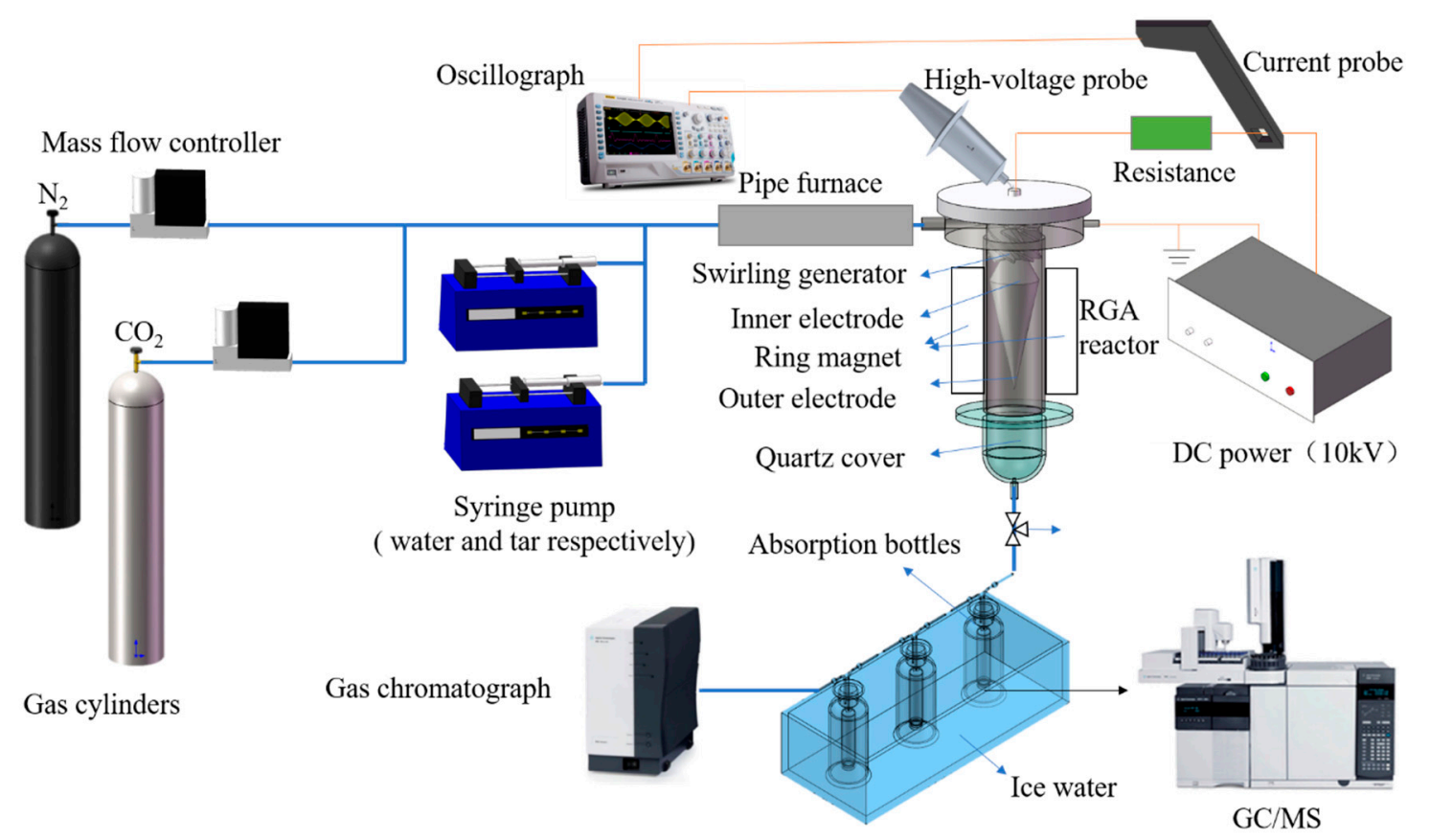

Figure 21. Schematics of the rotating gliding arc (RGA) assisted model tar destruction system.

Nitrogen was used as the carrier gas, and the flow rate was controlled by a mass flow controller (Sevenstar CS 200). Naphthalene and phenanthrene were dissolved in toluene with a mass ratio of 1:1:20 before mixing with $\mathrm{H}_{2} \mathrm{O}$ in the carrier gas. Liquid tar and $\mathrm{H}_{2} \mathrm{O}$ were injected into the gas line by two high-resolution syringe pumps (Harvard, 11 plus). Heating coils were put around the inlet of the gas line to ensure that the tar and water can be vaporized as soon as they enter into the pipe. All the reactants were mixed and preheated in a pipe furnace $\left(400^{\circ} \mathrm{C}\right)$ before flowing into the reactor. The gas flow after the reaction passed through three absorption bottles successively, the first two containing n-hexane and the third kept empty, to collect the entrained droplets and condensable liquid. The three absorption bottles were placed in an ice water bath.

The reactor consists of a thermostable ceramics base, a conical inner electrode (anode) and a grounded cylindrical outer electrode (cathode) as the wall of the reactor, both made of stainless steel $(18 / 8 \mathrm{Cr}-\mathrm{Ni})$. The upper part of the inner electrode is surrounded by a fan-shaped swirling generator to provide a stable swirling flow field. The outer electrode is surrounded by a ring magnet and with a quartz cover connected with it. The minimum distance between the inner and outer electrodes is $2 \mathrm{~mm}$ for the ignition of the discharge. Once the catalyst is used, $10 \mathrm{~g}$ of it is contained in a round quartz tray with a diameter slightly smaller than the cathode. The tray is placed downstream $(18 \mathrm{~mm}$ in vertical distance) the inner electrode. The gaseous reactants flow through the swirling generator to form a vortex flow before pass through the gliding arc. After being ignited initially at the narrowest gap, the arc moves down to the lower point of the conical electrode. Finally, it is anchored at the tip of the inner electrode and rotates rapidly and steadily due to the combined effect of vortex flow and Lorentz force, forming a stable cylindrical plasma zone.

A DC power supply (Teslaman TLP2040, $10 \mathrm{kV}$ ) is used in the circuit system. The voltage and discharge current of the reactor are measured by an oscillograph (Tektronix DPO4030B) equipped with a high-voltage probe (Tektronix P6015A) and discharge current probe (Tektronix TCP393) to calculate the electrical power deposit of the reactor.

The effluent gas of the reactor passes through three absorption bottles filled with n-hexane to collect the unreacted toluene, naphthalene, and phenanthrene. Each time the working condition kept changing, before the remaining tar was collected, $10 \mathrm{~min}$ passed before the reactor stabilized. A three-way valve is used to control the exhaust into absorption bottles or to the atmosphere. After 10 min collection, the liquid in all three absorption bottles is collected and diluted with 
$\mathrm{n}$-hexane to a final volume of $100 \mathrm{~mL}$. The gas products are collected in a gas bag after passing through the absorption bottles. The collected gas products are quantitatively analyzed by gas chromatography (Agilent Micro GC 490, Agilent Technologies Inc., Santa Clara, CA, USA) and the liquid products dissolved in the absorption solution are detected by the gas chromatography with mass spectrometry (GC/MS, Agilent 6890N GC/5977B MSD, Agilent Technologies Inc., Santa Clara, CA, USA). The column temperature of GC (Agilent Micro GC 490) is $80^{\circ} \mathrm{C}$. For the GC/MS detection, the initial temperature of the oven is $40^{\circ} \mathrm{C}$, holding time for $4 \mathrm{~min}$; the temperature increases to $140{ }^{\circ} \mathrm{C}$ at a rate of $15{ }^{\circ} \mathrm{C} / \mathrm{min}$, increases to $210^{\circ} \mathrm{C}$ at a rate of $20{ }^{\circ} \mathrm{C} / \mathrm{min}$, increases to $280{ }^{\circ} \mathrm{C}$ at a rate of $30{ }^{\circ} \mathrm{C} / \mathrm{min}$, then holds for $10 \mathrm{~min}$. The injector temperature is set to $300{ }^{\circ} \mathrm{C}$. Helium is used as the carrier gas, with a flow rate of $1.0 \mathrm{~mL} / \mathrm{min}$. For the mass spectrometer, the electron impact ionization is maintained at $70 \mathrm{eV}$, and the ion source temperature is $230^{\circ} \mathrm{C}$. The unreacted toluene, naphthalene, and phenanthrene are quantitatively detected based on the obtained calibration curve, and the other liquid by-products are qualitatively measured.

\subsection{Catalyst Preparation}

The $\mathrm{Ni} / \gamma-\mathrm{Al}_{2} \mathrm{O}_{3}$ catalyst was prepared using the impregnation method reported by Qian et al. [42], in which the $\gamma-\mathrm{Al}_{2} \mathrm{O}_{3}$ particles were added into an aqueous solution of nickel nitrate under stirring. The mixture was kept at room temperature overnight before being evaporated out at $80^{\circ} \mathrm{C}$. The solid was dried at $110^{\circ} \mathrm{C}$ for $10 \mathrm{~h}$ before final calcination at $700^{\circ} \mathrm{C}$ for $3 \mathrm{~h}$. The catalyst was formulated with $\mathrm{Ni}$ loadings of $16 \mathrm{wt} . \%$. The $\gamma-\mathrm{Al}_{2} \mathrm{O}_{3}$ particles are spherical with a diameter of $2 \mathrm{~mm}$.

\subsection{Reaction Performance Parameters}

The destruction efficiency $\eta_{d}$ (toluene, naphthalene or phenanthrene), energy efficiency $\eta_{e}$, hydrogen selectivity $\mathrm{S}\left(\mathrm{H}_{2}\right), \mathrm{CO}, \mathrm{CO}_{2}$ and $\mathrm{C}_{2} \mathrm{H}_{2}$ selectivity $\mathrm{S}\left(\mathrm{C}_{\mathrm{i}} \mathrm{H}_{\mathrm{j}} \mathrm{O}_{\mathrm{k}}, \mathrm{C}_{i} \mathrm{H}_{j} \mathrm{O}_{k}=\mathrm{C}_{2} \mathrm{H}_{2}, \mathrm{CO}, \mathrm{CO}_{2}\right)$, energy consumption per liter hydrogen production $\mathrm{W}\left(\mathrm{H}_{2}\right)$ is defined as in Equations (15)-(19).

$$
\begin{gathered}
\eta_{d}=\frac{c_{\text {in }}(X)-c_{\text {out }}(X)}{c_{\text {in }}(X)} \times 100 \% \\
\eta_{\mathrm{e}}=\frac{\left(\rho_{\text {in }}(\text { tar })-\rho_{\text {out }}(X)\right) \times Q / 60}{P / 3600000} \times 100 \% \\
S\left(H_{2}\right)=\frac{C_{\text {out }}\left(H_{2}\right)}{4 \times\left(C_{\text {in }}(\text { tar })-C_{\text {out }}(\text { tar })\right)} \times 100 \% \\
\left.i C_{i} H_{j} O_{k}\right)=\frac{i \times C_{\text {out }}\left(C_{i} H_{j} O_{k}\right)}{\left(14 \times\left(C_{\text {in }}\left(C_{14} H_{10}\right)-C_{\text {out }}\left(C_{14} H_{10}\right)\right)+10 \times\left(C_{\text {in }}\left(C_{10} H_{8}\right)-C_{\text {out }}\left(C_{10} H_{8}\right)\right)\right.} \\
\left.+7 \times\left(C_{\text {in }}\left(C_{7} H_{8}\right)-C_{\text {out }}\left(C_{7} H_{8}\right)\right)\right) \times 100 \% \\
W\left(H_{2}\right)=\frac{P / 1000}{C_{\text {out }}\left(H_{2}\right) \times Q / 60} \times 100 \%
\end{gathered}
$$

where, $c_{\text {in }}(X)$ and $C_{\text {out }}(X)(\mathrm{mol} / \mathrm{L})$ are the molar concentration of substance $X$ in the inflow gas and effluent gas respectively. $X$ is toluene or naphthalene.

$\rho_{\text {in }}($ tar $)$ and $\rho_{\text {out }}($ tar $)(\mathrm{g} / \mathrm{L})$ are the mass concentration of simulated tar (toluene and naphthalene) in the inflow gas and effluent gas respectively. $\mathrm{Q}(\mathrm{L} / \mathrm{min})$ is the total flow rate. $\mathrm{P}(\mathrm{W})$ is the power input on the reactor.

$\mathrm{C}_{\text {out }}\left(\mathrm{H}_{2}\right), \mathrm{C}_{\text {in }}($ tar $)$ and $\mathrm{C}_{\text {out }}($ tar $)(\mathrm{mol} / \mathrm{L})$ are the molar concentration of input $\mathrm{H}_{2}$, input simulated tar and output simulated tar respectively.

$\mathrm{C}_{\text {out }}\left(\mathrm{C}_{i} \mathrm{H}_{j} \mathrm{O}_{k}\right), \mathrm{C}_{\text {out }}\left(\mathrm{C}_{10} \mathrm{H}_{8}\right), \mathrm{C}_{\text {out }}\left(\mathrm{C}_{7} \mathrm{H}_{8}\right), \mathrm{C}_{\text {in }}\left(\mathrm{C}_{10} \mathrm{H}_{8}\right)$ and $\mathrm{C}_{\text {in }}\left(\mathrm{C}_{7} \mathrm{H}_{8}\right)(\mathrm{mol} / \mathrm{L})$ are the molar concentration of output $\mathrm{C}_{i} \mathrm{H}_{j} \mathrm{O}_{k}$, output naphthalene, output toluene, input naphthalene, and input toluene, respectively. 


\section{Conclusions}

In this study, a modified rotating gliding arc discharge reactor equipped with a fan-type swirling generator is developed for the destruction of model tar compounds (toluene, naphthalene, and phenanthrene). The influence of tar concentration, discharge current, different atmospheres $\left(\mathrm{CO}_{2}, \mathrm{H}_{2} \mathrm{O}\right)$, and the addition of catalyst on the destruction efficiency is investigated in this study. The destruction efficiency of all three tar components decreases as tar concentration increases, not only because of the limitation of the destruction capacity, but also the instability caused by the addition of phenanthrene. Mostly, $8 \%-12 \%$ of moisture benefits the reaction, while a further increase of moisture decreases the destruction efficiencies.

Although the participation of $\mathrm{CO}_{2}$ increases the energy consumption of the reaction, a moderate amount of it (about 15\%) improves the destruction efficiency by stabilizing the reactor, which is desirable. The toluene, naphthalene, and phenanthrene destruction efficiency reached up to $95.2 \%$, $88.9 \%$, and $83.9 \%$ respectively, with a tar content of $12 \mathrm{~g} / \mathrm{Nm}^{3}, 12 \%$ moisture content, and $15 \%$ $\mathrm{CO}_{2}$ content, with a flow rate of $6 \mathrm{NL} / \mathrm{min}$. Increasing the discharge current causes the increase of destruction efficiency slightly (by 3\%) but lowers the energy efficiency (by more than $10 \%$ ). It is notable that the increase of the discharge current can increase the selectivity of carbon-contained gas products from $80 \%$ to $88 \%$, as the discharge current increases from $200 \mathrm{~mA}$ to $250 \mathrm{~mA}$. The increased production of flammable gaseous products may not make up the power consumption in the reaction but decreasing black carbon production by almost $50 \%$ is extremely desirable.

The addition of $\mathrm{Ni} / \gamma-\mathrm{Al}_{2} \mathrm{O}_{3}$ catalyst shows little effect as the flow rate is low, but great improvement in destruction efficiency is achieved when flow rate is high ( 9 or $12 \mathrm{NL} / \mathrm{min}$ ), indicating that catalyst coupling with plasma is worth considering in industrial application to deal with large amounts of tars.

Author Contributions: Conceptualization, H.Z., X.L. and J.Y.; methodology, H.Z. and X.K.; investigation, X.K., R.X., L.L. and H.Z.; writing-original draft preparation, X.K.; writing-review and editing, H.Z. and I.M.; supervision, X.L. and J.Y.; funding acquisition, X.L. and J.Y.

Acknowledgments: This work was supported by the National Natural Science Foundation of China [No. 51576174, No. 51706204, No. 51621005] and the Fundamental Research Funds for the Central Universities (No. 2018FZA4010).

Conflicts of Interest: The authors declare no conflict of interest.

\section{References}

1. Sun, J.; Wang, Q.; Wang, W.; Song, Z.; Zhao, X.; Mao, Y.; Ma, C. Novel treatment of a biomass tar model compound via microwave-metal discharges. Fuel 2017, 207, 121-125. [CrossRef]

2. Wnukowski, M.; Jamróz, P. Microwave plasma treatment of simulated biomass syngas: Interactions between the permanent syngas compounds and their influence on the model tar compound conversion. Fuel Process. Technol. 2018, 173, 229-242. [CrossRef]

3. Luo, H.; Bao, L.; Wang, H.; Kong, L.; Sun, Y. Microwave-assisted in-situ elimination of primary tars over biochar: Low temperature behaviors and mechanistic insights. Bioresource Technol. 2018, 267, 333-340. [CrossRef] [PubMed]

4. Arena, U. Process and technological aspects of municipal solid waste gasification. A review. Waste Manag. 2012, 32, 625-639. [CrossRef] [PubMed]

5. Baratieri, M.; Baggio, P.; Bosio, B.; Grigiante, M.; Longo, G.A. The use of biomass syngas in IC engines and CCGT plants: A comparative analysis. Appl. Therm. Eng. 2009, 29, 3309-3318. [CrossRef]

6. Han, J.; Kim, H. The reduction and control technology of tar during biomass gasification/pyrolysis: An overview. Renew. Sustain. Energy Rev. 2008, 12, 397-416. [CrossRef]

7. Guan, G.; Kaewpanha, M.; Hao, X.; Wang, Z.; Cheng, Y.; Kasai, Y.; Abudula, A. Promoting effect of potassium addition to calcined scallop shell supported catalysts for the decomposition of tar derived from different biomass resources. Fuel 2013, 109, 241-247. [CrossRef]

8. Zhu, F.; Li, X.; Zhang, H.; Wu, A.; Yan, J.; Ni, M.; Zhang, H.; Buekens, A. Destruction of toluene by rotating gliding arc discharge. Fuel 2016, 176, 78-85. [CrossRef] 
9. Medeiros, H.S.; Pilatau, A.; Nozhenko, O.S.; Da Silva Sobrinho, A.S.; Petraconi Filho, G. Microwave Air Plasma Applied to Naphthalene Thermal Conversion. Energy Fuels 2016. [CrossRef]

10. Devi, L.; Ptasinski, K.J.; Janssen, F.J.J.G. Pretreated olivine as tar removal catalyst for biomass gasifiers: Investigation using naphthalene as model biomass tar. Fuel Process. Technol. 2005, 86, 707-730. [CrossRef]

11. Liu, S.; Mei, D.; Wang, L.; Tu, X. Steam reforming of toluene as biomass tar model compound in a gliding arc discharge reactor. Chem. Eng. J. 2017, 307, 793-802. [CrossRef]

12. Świerczyński, D.; Libs, S.; Courson, C.; Kiennemann, A. Steam reforming of tar from a biomass gasification process over Ni/olivine catalyst using toluene as a model compound. Appl. Catal. B Environ. 2009, 74, 211-222. [CrossRef]

13. Tursun, Y.; Xu, S.; Wang, G.; Wang, C.; Xiao, Y. Tar formation during co-gasification of biomass and coal under different gasification condition. J. Anal. Appl. Pyrolysis 2015, 111, 191-199. [CrossRef]

14. Jess, A. Mechanisms and kinetics of thermal reactions of aromatic hydrocarbons from pyrolysis of solid fuels. Fuel 1996, 75, 1441-1448. [CrossRef]

15. Saleem, F.; Zhang, K.; Harvey, A. Role of $\mathrm{CO}_{2}$ in the Conversion of Toluene as a Tar Surrogate in a Nonthermal Plasma Dielectric Barrier Discharge Reactor. Energy Fuels 2018, 32, 5164-5170. [CrossRef]

16. Richardson, Y.; Blin, J.; Julbe, A. A short overview on purification and conditioning of syngas produced by biomass gasification: Catalytic strategies, process intensification and new concepts. Prog. Energy Combust. Sci. 2012, 38, 765-781. [CrossRef]

17. Nunnally, T.; Tsangaris, A.; Rabinovich, A.; Nirenberg, G.; Chernets, I.; Fridman, A. Gliding arc plasma oxidative steam reforming of a simulated syngas containing naphthalene and toluene. Int. J. Hydrogen Energy 2014, 39, 11976-11989. [CrossRef]

18. Chun, Y.N.; Kim, S.C.; Yoshikawa, K. Destruction of anthracene using a gliding arc plasma reformer. Korean J. Chem. Eng. 2011, 28, 1713-1720. [CrossRef]

19. Ashok, J.; Kawi, S. Steam reforming of toluene as a biomass tar model compound over $\mathrm{CeO}_{2}$ promoted $\mathrm{Ni} / \mathrm{CaO}-\mathrm{Al}_{2} \mathrm{O}_{3}$ catalytic systems. Int. J. Hydrogen Energy 2013, 38, 13938-13949. [CrossRef]

20. Nair, S.A.; Pemen, A.J.M.; Yan, K.; Gompel, F.M.V.; Leuken, H.E.M.V.; Heesch, E.J.M.V.; Ptasinski, K.J.; Drinkenburg, A.A.H. Tar removal from biomass-derived fuel gas by pulsed corona discharges. Fuel Process. Technol. 2003, 84, 161-173. [CrossRef]

21. Pemen, A.J.M.; Nair, S.A.; Yan, K.; Heesch, E.J.M.V.; Ptasinski, K.J.; Drinkenburg, A.A.H. Pulsed Corona Discharges for Tar Removal from Biomass Derived Fuel Gas. Plasmas Polym. 2003, 8, 209-224. [CrossRef]

22. Sun, J.; Wang, Q.; Wang, W.; Wang, K. Exploiting the Photocatalytic Effect of Microwave-Metal Discharges for the Destruction of a Tar Model Compound. Energy Fuels 2018, 32, 241-245. [CrossRef]

23. Jamróz, P.; Kordylewski, W.; Wnukowski, M. Microwave plasma application in decomposition and steam reforming of model tar compounds. Fuel Process. Technol. 2018. [CrossRef]

24. Wnukowski, M. Decomposition of Tars in Microwave Plasma-Preliminary Results. J. Ecol. Eng. 2014, 15, 23-28.

25. Materazzi, M.; Lettieri, P.; Mazzei, L.; Taylor, R.; Chapman, C. Reforming of tars and organic sulphur compounds in a plasma-assisted process for waste gasification. Fuel Process. Technol. 2015, 137, 259-268. [CrossRef]

26. Materazzi, M.; Lettieri, P.; Mazzei, L.; Taylor, R.; Chapman, C. Tar evolution in a two-stage fluid bed-plasma gasification process for waste valorization. Fuel Process. Technol. 2014, 128, 146-157. [CrossRef]

27. Lim, M.; Chun, Y. Light Tar Decomposition of Product Pyrolysis Gas from Sewage Sludge in a Gliding Arc Plasma Reformer. Environ. Eng. Res. 2012, 17, 89-94. [CrossRef]

28. Yang, Y.C.; Chun, Y.N. Naphthalene destruction performance from tar model compound using a gliding arc plasma reformer. Korean J. Chem. Eng. 2011, 28, 539-543. [CrossRef]

29. Tippayawong, N.; Inthasan, P. Investigation of Light Tar Cracking in a Gliding Arc Plasma System. Int. J. Chem. React. Eng. 2010. [CrossRef]

30. Du, C.M.; Yan, J.H.; Cheron, B. Decomposition of toluene in a gliding arc discharge plasma reactor. Plasma Sources Sci. Technol. 2007, 16, 791-797. [CrossRef]

31. Snoeckx, R.; Bogaerts, A. Plasma technology-A novel solution for $\mathrm{CO}_{2}$ conversion. Chem. Soc. Rev. 2017, 46, 585-586. [CrossRef] 
32. Pemen, A.J.M.; van Paasen, S.V.B.; Yan, K.; Nair, S.A.; van Heesch, E.J.M.; Ptasinski, K.J.; Neeft, J.P.A. Conditioning of biomass derived fuel gas using plasma techniques. In Proceedings of the 12th European Conference on Biomass for Energy, Industry and Climate Protection, Amsterdam, The Netherlands, 17-21 June 2002.

33. Nunnally, T.P.; Gutsol, A.; Fridman, A. Dissociation of $\mathrm{H}_{2} \mathrm{~S}$ in non-equilibrium gliding arc 'tornado' discharge. Int. J. Hydrogen Energy 2009, 34, 7618-7625. [CrossRef]

34. Fridman, A.; Nester, S.; Kennedy, L.A.; Saveliev, A.; Mutaf-Yardimci, O. Gliding arc gas discharge. Prog. Energy Combust. Sci. 1999, 25, 211-231. [CrossRef]

35. Zhang, H.; Zhu, F.; Li, X.; Cen, K.; Du, C.; Tu, X. Rotating Gliding Arc Assisted Water Splitting in Atmospheric Nitrogen. Plasma Chem. Plasma Process. 2016, 36, 813-834. [CrossRef]

36. Zhu, F.; Zhang, H.; Yang, J.; Yan, J.; Ni, M.; Li, X. Plasma-assisted Toluene Destruction in Simulated Producer Gas. Chem. Lett. 2017, 46, 1341-1343. [CrossRef]

37. Materazzi, M.; Lettieri, P.; Taylor, R.; Chapman, C. Performance analysis of RDF gasification in a two-stage fluidized bed-plasma process. Waste Manag. 2016, 47, 256-266. [CrossRef]

38. Ma, W.; Han, L.; Zhang, L.; Lu, W. Thermal-reforming of toluene over core-shell Ni/ $\gamma-\mathrm{Al}_{2} \mathrm{O}_{3}$ catalysts. In Proceedings of the IEEE International Conference on Materials for Renewable Energy \& Environment, Chengdu, China, 19-21 August 2014.

39. Chun, Y.N.; Kim, S.C.; Yoshikawa, K. Decomposition of benzene as a surrogate tar in a gliding arc plasma. Environ. Prog. Sustain. 2013, 32, 837-845. [CrossRef]

40. Gao, J.; Zhu, J.; Ehn, A.; Aldén, M.; Li, Z. In-Situ Non-intrusive Diagnostics of Toluene Removal by a Gliding Arc Discharge Using Planar Laser-Induced Fluorescence. Plasma Chem. Plasma Process. 2017, 37, 433-450. [CrossRef]

41. Yan, X.; Li, X.D.; Zhu, F.S.; Kong, X.Z.; Yan, J.H. Decomposition of naphthalene as tar model compound from the gasification of municipal solid waste by rotating gliding arc plasma. Chem. Ind. Eng. Prog. 2018, 37, 1174-1180.

42. Qian, N.; Zhang, L.; Ma, W.; Zhao, X.; Han, L.; Lu, W. Core-Shell $\mathrm{Al}_{2} \mathrm{O}_{3}$-Supported Ni for High-Performance Catalytic Reforming of Toluene as a Model Compound of Tar. Arab. J. Sci. Eng. 2014, 39, 6671-6678. [CrossRef] 